\title{
Measurement report: The effect of aerosol chemical composition on light scattering due to the hygroscopic swelling effect
}

\author{
Rongmin Ren ${ }^{1}$, Zhanqing $\mathrm{Li}^{2}$, Peng Yan $^{3}$, Yuying Wang ${ }^{4}$, Hao Wu ${ }^{5}$, Maureen Cribb ${ }^{2}$, Wei Wang ${ }^{1}$, Xiao'ai Jin ${ }^{1}$, \\ Yanan $\mathrm{Li}^{3}$, and Dongmei Zhang ${ }^{1}$ \\ ${ }^{1}$ State Key Laboratory of Remote Sensing Science, College of Global Change and Earth System Science, \\ Beijing Normal University, Beijing 100875, China \\ ${ }^{2}$ Earth System Science Interdisciplinary Center, Department of Atmospheric and Oceanic Science, \\ University of Maryland, College Park, MD, USA \\ ${ }^{3}$ Centre for Atmosphere Watch and Service, Meteorological Observation Center of China Meteorological Administration, \\ Beijing, China \\ ${ }^{4}$ Key Laboratory for Aerosol-Cloud-Precipitation of China Meteorological Administration, School of Atmospheric Physics, \\ Nanjing University of Information Science and Technology, Nanjing 210044, China \\ ${ }^{5}$ School of Electrical Engineering, Chengdu University of Information Technology, Chengdu 610225, China
}

Correspondence: Zhanqing Li (zli@atmos.umd.edu)

Received: 4 December 2020 - Discussion started: 18 January 2021

Revised: 18 May 2021 - Accepted: 19 May 2021 - Published: 2 July 2021

\begin{abstract}
Liquid water in aerosol particles has a significant effect on their optical properties, especially on light scattering, whose dependence on chemical composition is investigated here using measurements made in southern Beijing in 2019. The effect is measured by the particle light scattering enhancement $f(\mathrm{RH})$, where $\mathrm{RH}$ denotes the relative humidity, which is found to be positively and negatively impacted by the proportions of inorganic and organic matter, respectively. Black carbon is also negatively correlated. The positive impact is more robust when the inorganic matter mass fraction was smaller than $40 \%(R=0.93, R$ : the Pearson's correlation coefficient), becoming weaker as the inorganic matter mass fraction gets larger $(R=0.48)$. A similar pattern was also found for the negative impact of the organic matter mass fraction. Nitrate played a more significant role in aerosol hygroscopicity than sulfate in Beijing. However, the deliquescence point of ambient aerosols was at about $\mathrm{RH}=80 \%$ when the ratio of the sulfate mass concentration to the nitrate mass concentration of the aerosol was high (mostly higher than $\sim 4$ ). Two schemes to parameterize $f(\mathrm{RH})$ were developed to account for the deliquescent and non-deliquescent effects. Using only one $f(\mathrm{RH})$ parameterization scheme to fit all $f(\mathrm{RH})$ processes incurs large errors. A piecewise parameterization scheme is proposed, which can
\end{abstract}

better describe deliquescence and reduces uncertainties in simulating aerosol hygroscopicity.

\section{Introduction}

Atmospheric aerosols have impacts on visibility, the earthatmosphere radiation budget, clouds, and precipitation via direct and indirect effects (IPCC, 2013). Both effects are associated with the hygroscopic properties of aerosols and relative humidity $(\mathrm{RH})$ of the atmosphere. The particle light scattering enhancement factor, $f(\mathrm{RH}, \lambda)$, is the ratio of the scattering coefficient at an elevated $\mathrm{RH}$ level to that under a fixed low $\mathrm{RH}$ level (usually $\mathrm{RH}<40 \%$ ) at a certain light wavelength $(\lambda)$. It has been characterized during international field experiments (Fierz-Schmidhauser et al., 2010a, b; Zieger et al., 2010, 2014) and in particular China (Yan et al., 2009; Zhang et al., 2015; Kuang et al., 2016; L. Liu et al., 2018; C. Zhao et al., 2019; Zhao, 2019; Wu et al., 2020).

Aerosol chemical composition has a strong impact on aerosol hygroscopicity (Fierz-Schmidhauser et al., 2010a, b; Wang et al., 2017, 2018, 2019). Zhang et al. (2015) studied the relationship between the scattering enhancement factor and chemical composition in Lin'an, China, finding that 
nitrate has a stronger effect on aerosol hygroscopicity than sulfate has, which is partially due to the rigid control of sulfur dioxide $\left(\mathrm{SO}_{2}\right)$ that reduces the amount of sulfate and increases the content of nitrite (Morgan et al., 2010). Apart from sea salt emissions and gypsum dust emissions during construction containing sulfate, sulfate is mainly formed by the oxidation of its gaseous precursor, $\mathrm{SO}_{2}$, in the atmosphere. In recent years, $\mathrm{SO}_{2}$ emissions have been reduced substantially through a series of effective measures taken in China, like controlling the burning of loose coal and desulfurizing industrial equipment (Zhang et al., 2019). Reducing $\mathrm{SO}_{2}$ in the atmosphere thus directly affects the reduction in the sulfate content of aerosols. The saturated vapor pressure of nitric acid $\left(\mathrm{HNO}_{3}\right)$ is higher than that of sulfuric acid $\left(\mathrm{H}_{2} \mathrm{SO}_{4}\right)$, so the availability of ammonia $\left(\mathrm{NH}_{3}\right)$ is key to the partitioning of $\mathrm{HNO}_{3}$. $\mathrm{HNO}_{3}$ is often neutralized by $\mathrm{NH}_{3}$ after $\mathrm{H}_{2} \mathrm{SO}_{4}$. Therefore, a reduction in $\mathrm{SO}_{2}$ means that more $\mathrm{NH}_{3}$ can be used to neutralize $\mathrm{HNO}_{3}$, leading to higher nitrate concentrations, such as ammonium nitrate $\left(\mathrm{HN}_{4} \mathrm{NO}_{3}\right)$, in aerosols (Monks et al., 2009). Zieger et al. (2014) analyzed the correlation between the chemical composition of aerosols and $f(\mathrm{RH}=85 \%, 550 \mathrm{~nm})$ in Melpitz, Germany, and noted negative and positive impacts by organic and black carbon and by inorganic substances, such as ammonium, respectively. However, the correlation between the mass fractions of individual nitrate $\left(\mathrm{NO}_{3}^{-}\right)$and sulfate $\left(\mathrm{SO}_{4}^{2-}\right)$ ions and $f(\mathrm{RH}=85 \%, 550 \mathrm{~nm})$ were weak. Zieger et al. (2015) also found that the mass fraction of sulfates was strongly correlated with scattering enhancement, while the mass fraction of nitrates had a low correlation in Hyytiälä, Finland. Jin et al. (2020) reported that apart from inorganic matter, e.g., $\mathrm{SO}_{4}^{2-}$ and $\mathrm{NO}_{3}^{-}$, organic species also significantly contributed to the aerosol liquid water content. They proposed that in the initial phase of a pollution event, the aerosol liquid water content contributed by organic matter accelerated aqueous-phase reactions, converting gaseous precursors into secondary aerosols which then absorb more liquid water.

Air pollution has been and continues to be a serious problem in China, especially in megacities like Beijing. A high scattering enhancement factor is one of the most important factors causing degradation in visibility. Some observational studies of the light hygroscopicity enhancement factor in Beijing have been conducted (Liu et al., 2013; Yang et al., 2015; Zhao et al., 2018; P. Zhao et al., 2019). However, studies exploring the relationship between aerosol chemical composition and the particle light scattering enhancement factor are lacking. Moreover, although several optimal expressions of $f(\mathrm{RH}, \lambda)$ for different seasons have been developed (Pan et al., 2009; Yan et al., 2009; Kuang et al., 2016; Wu et al., 2017; Yu et al., 2018; P. Zhao et al., 2019), parameterization of the deliquescent curve of $\mathrm{SO}_{4}^{2-}$ in ambient aerosols has not yet been done for the Beijing-Tianjin-Hebei (BTH) metropolitan region, where aerosol deliquescent phenomena frequently occur (Kuang et al., 2016). It is thus important to develop an optimal parameterization to describe this deliquescent phenomenon to improve model simulations of aerosol hygroscopicity.

In this study, $f(\mathrm{RH}, \lambda)$ at three wavelengths for RH ranging from $40 \%$ to about $90 \%$ was measured by a highresolution humidified nephelometer system deployed in the southern suburban area of Beijing, China. Other aerosol chemical and physical properties were also simultaneously measured. Humidograms were classified into two categories, i.e., deliquescent and non-deliquescent, each parameterized separately. The parameterization results of deliquescent processes agreed well with observations. This result is useful for improving simulations of $f(\mathrm{RH}, \lambda)$ of ambient aerosols during deliquescence in the BTH metropolitan region.

The paper is organized as follows. Section 2 describes the instruments and methods. Section 3 presents and discusses the results of this study, and Sect. 4 provides a summary.

\section{Instruments and methods}

\subsection{Observation site}

A comprehensive field experiment was conducted at the climate observatory of the China Meteorological Administration, located in Yizhuang, Beijing, near the southern Fifth Ring Beltway $\left(39.81^{\circ} \mathrm{N}, 116.48^{\circ} \mathrm{E}\right)$ surrounded primarily by residential communities and industrial parks (Fig. S1 in the Supplement). Measurements made here can characterize the aerosol chemical and physical properties of a typical suburban area of this megacity in the North China Plain. Equipped with a multitude of instruments measuring, for example, optical, hygroscopic, and chemical properties of aerosols ( $\mathrm{Z}$. Li et al., 2019), this study employs only those measurements acquired from 19 September to 4 October 2019. The instruments used in this field experiment include a dual-nephelometer system (Aurora 3000, Ecotech), an aerosol chemical speciation monitor (ACSM; Aerodyne Research Inc.), and a seven-wavelength aethalometer (AE33, Magee Scientific). They were all located in a mobility container on the ground. There are two air conditioners inside the container whose temperature was maintained at about $23^{\circ} \mathrm{C}$. Sample air $\left(16.7 \mathrm{~L} \mathrm{~min}^{-1}\right)$ went through a $\mathrm{PM}_{2.5}$ cyclone inlet at about $4 \mathrm{~m}$ above the ground, which only allowed particles with an aerodynamic diameter smaller than $2.5 \mu \mathrm{m}$ to enter, and was then dried by a Nafion dryer (MD-700-36F-3, Perma Pure LLC). The average RH within the sampling line was about $30 \%$. The sample air was not heated.

\subsection{Instruments}

A dual-nephelometer system with a high time resolution was used to measure the particle light scattering enhancement factor of aerosol. After an aerosol sample passed through the Nafion dryer, the dry sample flow ( $\mathrm{RH}<40 \%$ ) was divided into two routes. One sample flow $\left(5 \mathrm{~L} \mathrm{~min}^{-1}\right)$ went directly into the dry nephelometer. The other sample flow $\left(5 \mathrm{~L} \mathrm{~min}^{-1}\right)$ 
passed through an annular concentric humidifying tube (MD700-6F-3, Perma Pure LLC). The water vapor controlled by the temperature of the liquid water in the outer annulus of the tube passes through a Nafion membrane, humidifying aerosols in the inner tube (Carrico et al., 1998). The temperature of the liquid water was controlled by adjusting the power of the water baths. The sample flow was then humidified to a given RH and channeled into the wet nephelometer. The scattering coefficients under dry (the mean \pm standard deviation value of $\mathrm{RH}$ was $28.75 \pm 5.50 \%$ ) and wet ambient conditions were measured synchronously by the two nephelometers (Yan et al., 2009). To improve the performance of this system and to decrease the amount of time needed to undergo one aerosol humidifying process, two water baths were used in turn to heat the water circulating in the interior layer of the humidifying tube (Liu and Zhao, 2016).

Since the RH of aerosols inside the nephelometers was constantly changing and real measured data at every moment were needed, the nephelometers operated without Kalman filters. Manual "full calibration" and zero check and span check of the two nephelometers were performed at 10:30 (all times in Beijing time, UTC $+8 \mathrm{~h}$ ) on 19 September 2019. The calibration tolerance of the zero check was $\pm 2 \mathrm{Mm}^{-1}$, and that of the span check was $\pm 2 \%$ of the span point. Calibrations of the two nephelometers in the dry state were consistent (Fig. S2). The truncation and illumination correction of the scattering coefficients has been done following Müller et al. (2011), which was developed specifically for Ecotech nephelometers originating from Anderson and Ogren (1998) for TSI nephelometers. For the $f(\mathrm{RH})$ calculations, there is no truncation and illumination correction applied to the scattering coefficients of both dry and humidified types of nephelometer. The comparison of the deviation between corrected and uncorrected $f(\mathrm{RH}=85 \%, 525 \mathrm{~nm})$ is shown in Fig. S3. The linear least square regression slop \pm standard deviation is $1.064 \pm 0.002$, the intercept \pm standard deviation is $-0.082 \pm 0.004$, and $R$ is 0.999 . The fitted line is very close to the line of $1: 1$. The uncorrected $f(\mathrm{RH}=85 \%$, $525 \mathrm{~nm})$ is a little lower than the corrected $f(\mathrm{RH}=85 \%$, $525 \mathrm{~nm})$.

Because the RH levels measured by the probe built into the optical chamber of the wet nephelometer $\left(\mathrm{RH}_{\text {chamber }}\right)$ were imprecise, the $\mathrm{RH}_{\text {chamber }}$ was corrected in this paper. First, a set of calibrated RH and temperature probes was placed at the inlet of the wet nephelometer, and another set was placed at the outlet of the wet nephelometer, obtaining $1 \mathrm{~min}$ averages of RH and temperature. We used Vaisala HMP110 probes with accuracies of $\pm 0.2^{\circ} \mathrm{C}$ for the $0-40^{\circ} \mathrm{C}$ temperature range and $\pm 1.5 \% \mathrm{RH}$ and $\pm 2.5 \% \mathrm{RH}$ for the $0 \% \mathrm{RH}-$ $90 \% \mathrm{RH}$ and $90 \% \mathrm{RH}-100 \% \mathrm{RH}$ ranges, respectively. The temperatures measured by these three probes were different. However, in principle, the dew point temperatures ( $\left.T_{\text {dew-point }}\right)$ at these three positions are all the same. Since the RH and temperature probes at the outlet of the wet nephelometer $\left(\mathrm{RH}_{\text {outlet }}\right.$ and $\left.T_{\text {outlet }}\right)$ were less affected by the humidifier,
$\mathrm{RH}_{\text {outlet }}$ and $T_{\text {outlet }}$ were used to calculate $T_{\text {dew-point }}$ at this position using Eq. (1) (Wanielista et al., 1997; James et al., 2015):

$T_{\text {dew-point }}=\mathrm{RH}_{\text {outlet }}^{\frac{1}{8}}\left(112+0.9 T_{\text {outlet }}\right)+0.1 T_{\text {outlet }}-112$.

We assume that $T_{\text {dew-point }}$ was approximately the same as that in the optical chamber of the wet nephelometer. Based on the temperature in the optical chamber $\left(T_{\text {chamber }}\right)$ and $T_{\text {dew-point }}$, the actual $\mathrm{RH}$ in the optical chamber $\left(\mathrm{RH}_{\text {chamber }}\right)$ can be calculated by rearranging Eq. (1), i.e.,

$\mathrm{RH}_{\text {chamber }}=\left(\frac{112-0.1 T_{\text {chamber }}+T_{\text {dew-point }}}{112+0.9 T_{\text {chamber }}}\right)$.

The dual-nephelometer system with a high time resolution in this study was calibrated with ammonium sulfate, $\left(\mathrm{NH}_{4}\right)_{2} \mathrm{SO}_{4}$, whose deliquescence $\mathrm{RH}(\mathrm{DRH})$ was $80 \%$ at $298 \mathrm{~K}$ (Cheung et al., 2015). Figure S4 shows that the measured phase transition occurs at $\mathrm{RH}=80.37 \%$. It illustrates that the RH inside the nephelometer chamber is correct and that the system is functioning properly.

An ACSM measured the mass concentrations of nonrefractory aerosol chemical species, including $\mathrm{SO}_{4}^{2-}, \mathrm{NO}_{3}^{-}$, ammonium $\left(\mathrm{NH}_{4}^{+}\right)$, chlorine $(\mathrm{Chl})$, and organics (Orgs) in particulate matter with diameters less than $2.5 \mu \mathrm{m}\left(\mathrm{PM}_{2.5}\right)$. The mass concentration of the equivalent black carbon (eBC) could be retrieved from the measurements of AE33. The Chinese Ministry of Ecology and Environment network and the Beijing Municipal Environmental Monitoring Center (http: //106.37.208.233:20035/, last access: 1 June 2021 and http: //www.bjmemc.com.cn/, last access: 1 June 2021) provided mass concentrations of $\mathrm{PM}_{2.5}$ measured at the Yizhuang station, about $3 \mathrm{~km}$ southeast of the observatory. The LI-COR eddy covariance system (this system includes WindMaster Pro, LI-7500A, and Smart2-00171, LI-COR) measured various meteorological parameters.

\subsection{Methods}

The particle light scattering enhancement factor, $f(\mathrm{RH}, \lambda)$, is defined as

$f(\mathrm{RH}, \lambda)=\frac{\sigma_{\mathrm{sp}}(\mathrm{RH}, \lambda)}{\sigma_{\mathrm{sp}}\left(\mathrm{RH}_{\mathrm{dry}}, \lambda\right)}$,

where $\sigma_{\mathrm{sp}}(\mathrm{RH}, \lambda)$ represents the scattering coefficient at an elevated $\mathrm{RH}$ (usually $\mathrm{RH}>40 \%$ ), and $\sigma_{\mathrm{sp}}\left(\mathrm{RH}_{\text {dry }}, \lambda\right)$ is the scattering coefficient in the dry state (usually $\mathrm{RH}<40 \%$ ) at wavelength $\lambda$. Values of $f(\mathrm{RH}, \lambda)$ are generally greater than 1 and increase with increasing RH. In this study, we assume that the aerosol is in the dry state when $\mathrm{RH}<40 \%$. This means that in theory, $f(\mathrm{RH})$ should equal 1 when $\mathrm{RH}$ is lower than $40 \%$. However, due to systematic errors and differences in RH measured synchronously by the dry nephelometer and the wet nephelometer, the measured 
$f(\mathrm{RH}<40 \%)$ has small fluctuations and does not equal 1 . Therefore, $f(\mathrm{RH}>40 \%)$ was normalized as

$$
f(\mathrm{RH}>40 \%)_{\text {normalized }}=\left(\frac{f(\mathrm{RH}>40 \%)}{f(\mathrm{RH}<40 \%)_{\text {averaged }}}\right) .
$$

Here, $f(\mathrm{RH}<40 \%)_{\text {averaged }}$ is the corrected coefficient averaged over the whole dataset of $\mathrm{RH}<40 \%$.

The absorption coefficient of $\mathrm{PM}_{2.5}$ at $520 \mathrm{~nm}$ was calculated by the eBC monitor (Han et al., 2015; Zou et al., 2019). To facilitate comparisons, absorption coefficients at $520 \mathrm{~nm}$ were transformed into those at $525 \mathrm{~nm}$ by assuming that the absorption coefficient is inversely proportional to the wavelength (Bond and Bergstrom, 2006; C. Liu et al., 2018). The quantity $\omega_{0(525 \mathrm{~nm})}$ is the aerosol single-scattering albedo at $525 \mathrm{~nm}$. The dependence of light scattering on wavelength is described by the Ångström exponent $\left(\alpha_{\left(\lambda_{1}-\lambda_{2}\right)}\right)$, an index describing the particle size:

$\alpha_{\left(\lambda_{1}-\lambda_{2}\right)}=\frac{\log \sigma_{\mathrm{sp}}\left(\lambda_{1}\right)-\log \sigma_{\mathrm{sp}}\left(\lambda_{2}\right)}{\log \lambda_{2}-\log \lambda_{1}}$.

Here, $\alpha_{(450-635 \mathrm{~nm})}$ between 450 and $525 \mathrm{~nm}$ was calculated using Eq. (5).

The following parameter $\left(F_{\text {org }}\right)$ denotes the relative amount of organic and inorganic matter:

$F_{\text {org }}=\frac{C_{\mathrm{c}}}{C_{\mathrm{c}}+C_{\mathrm{i}}}$,

where $C_{\mathrm{c}}$ is the organic matter mass concentration measured by the ACSM, and $C_{\mathrm{i}}$ represents the mass concentration of inorganic salts like $\left(\mathrm{NH}_{4}\right)_{2} \mathrm{SO}_{4}$, ammonium bisulfate $\left(\mathrm{NH}_{4} \mathrm{HSO}_{4}\right)$, and ammonium nitrate $\left(\mathrm{NH}_{4} \mathrm{NO}_{3}\right)$.

Deliquescence of ambient aerosols was present throughout the study period. To identify this process and describe its magnitude in the $78 \% \mathrm{RH}-82 \% \mathrm{RH}$ range, the hysteresis index $\eta$ is defined as (Zieger et al., 2010)

$\eta=1-\frac{\gamma_{<78 \%}}{\gamma_{>82 \%}}$

The terms $\gamma<78 \%$ and $\gamma_{>82} \%$ are the fit parameters of the $f(\mathrm{RH})$ parametrization scheme,

$f(\mathrm{RH})=(1-\mathrm{RH})^{-\gamma}$,

at $\mathrm{RH}<78 \%$ and $\mathrm{RH}>82 \%$, respectively. The parameter $\gamma$ is retrieved from Eq. (8) using the whole RH range. It can replace $f(\mathrm{RH})$ in a wider $\mathrm{RH}$ range (Doherty et al., 2005; Quinn et al., 2005; Zhang et al., 2015). The theoretical range of $\eta$ is 0 to 1 . The $\gamma<78 \%$ and $\gamma>82 \%$ terms, respectively, represent the magnitudes of the scattering enhancement when $\mathrm{RH}<78 \%$ and $\mathrm{RH}>82 \%$. If the values of $\gamma<78 \%$ and $\gamma>82 \%$ are about the same, then $\eta$ will be close to 0 . This suggests that $f(\mathrm{RH})$ increases slowly and continuously when $78 \%<\mathrm{RH}<82 \%$, and no deliquescence is found. However, when the value of $\gamma_{>82} \%$ is much higher than $\gamma<78 \%, \eta$ approaches 1 . This explains why the $f(\mathrm{RH})$ cycle has a jump at $78 \%<\mathrm{RH}<82 \%$, i.e., very distinct deliquescence occurring in the $\mathrm{RH}$ range of $78 \%$ to $82 \%$. Here, when $\eta$ is higher than 0.4 , deliquescence occurs.

\section{Results and discussion}

\subsection{Overview}

Figure 1 depicts the hourly averaged time series of the light-scattering coefficient $\left(\sigma_{\mathrm{sp}, 525 \mathrm{~nm}}\right)$, the absorption coefficient $\left(\sigma_{\mathrm{ap}, 525 \mathrm{~nm}}\right)$, the single-scattering albedo $\left(\omega_{0(525 \mathrm{~nm})}\right)$, the scattering Ångström exponent $\left(\alpha_{(450-635 \mathrm{~nm})}\right)$, and the particle light scattering enhancement factor at $\mathrm{RH}=85 \%$, $f(\mathrm{RH}=85 \%, 525 \mathrm{~nm})$, at the main observatory, and the mass concentration of $\mathrm{PM}_{2.5}$ measured at the Yizhuang station from 19 September to 4 October 2019. During this period, the hourly averaged $\sigma_{\mathrm{sp}, 525 \mathrm{~nm}}$ ranged from 3 to $799 \mathrm{Mm}^{-1}$ (Fig. 1a), with a mean \pm standard deviation value of $245 \pm 168 \mathrm{Mm}^{-1}$ (Table 1 ). The hourly averaged $\sigma_{\text {ap }, 525 \mathrm{~nm}}$ varied from 7 to $135 \mathrm{Mm}^{-1}$ (Fig. 1b), with a mean \pm standard deviation value of $50 \pm 24 \mathrm{Mm}^{-1}$ (Table 1). Figure $1 \mathrm{c}$ and $\mathrm{f}$ show that $\omega_{0}(525 \mathrm{~nm})$ increased as the $\mathrm{PM}_{2.5}$ concentration increased. The hourly averaged $\omega_{0(525 \mathrm{~nm})}$ during the observation period ranged from 0.24 to 0.98 , with an overall mean \pm standard deviation value of $0.77 \pm 0.15$. The mean \pm standard deviation values of $\omega_{0(525 \mathrm{~nm})}$ during clean $\left(\mathrm{PM}_{2.5} \leq 35 \mu \mathrm{g} \mathrm{m}^{-3}\right)$, moderately polluted $\left(35 \mu \mathrm{g} \mathrm{m}^{-3}<\mathrm{PM}_{2.5} \leq 75 \mu \mathrm{g} \mathrm{m}^{-3}\right)$, and heavily polluted $\left(\mathrm{PM}_{2.5}>75 \mu \mathrm{g} \mathrm{m}^{-3}\right)$ periods were $0.65 \pm 0.16$, $0.83 \pm 0.08$, and $0.93 \pm 0.04$, respectively (Table 1 ).

The $\omega_{0}(525 \mathrm{~nm})$ increased as $\mathrm{PM}_{2.5}$ pollution increased, indicating that during the contamination process, the proportion of aerosol components with strong scattering properties increased, and the proportion of aerosol components with strong absorbing properties decreased. Higher values of $\omega_{0}(525 \mathrm{~nm})$ usually occurred when the wind was from the northeast at a speed of $1-2 \mathrm{~m} \mathrm{~s}^{-1}$ and when relatively stronger winds were from the southeast (Fig. 2a), which was frequently accompanied by a high proportion of inorganic matter (Fig. 2e) and low proportions of eBC (Fig. 2d) and organic matter (Fig. 2f). Figure 1d shows that the range of $\alpha_{(450-635 \mathrm{~nm})}$ was narrow at most times during the observation period. Relatively larger particles with lower values of $\alpha_{(450-635 \mathrm{~nm})}$ generally occurred when weak winds were from the east and southeast (Fig. 2b).

During the observation period, $f(\mathrm{RH}=85 \%, 525 \mathrm{~nm})$ ranged from 1.15 to 1.86 , meaning a $1.15-$ to 1.86 -fold increase in the scattering coefficient at $\mathrm{RH}=85 \%$ compared to dry conditions (Fig. 1e). Daily average values of $f(\mathrm{RH}=85 \%, 525 \mathrm{~nm})$ varied between 1.32 and 1.74, with low values $(<1.40)$ on 19 and 24 September and relatively high values $(>1.70)$ on 22 and 28 September and 


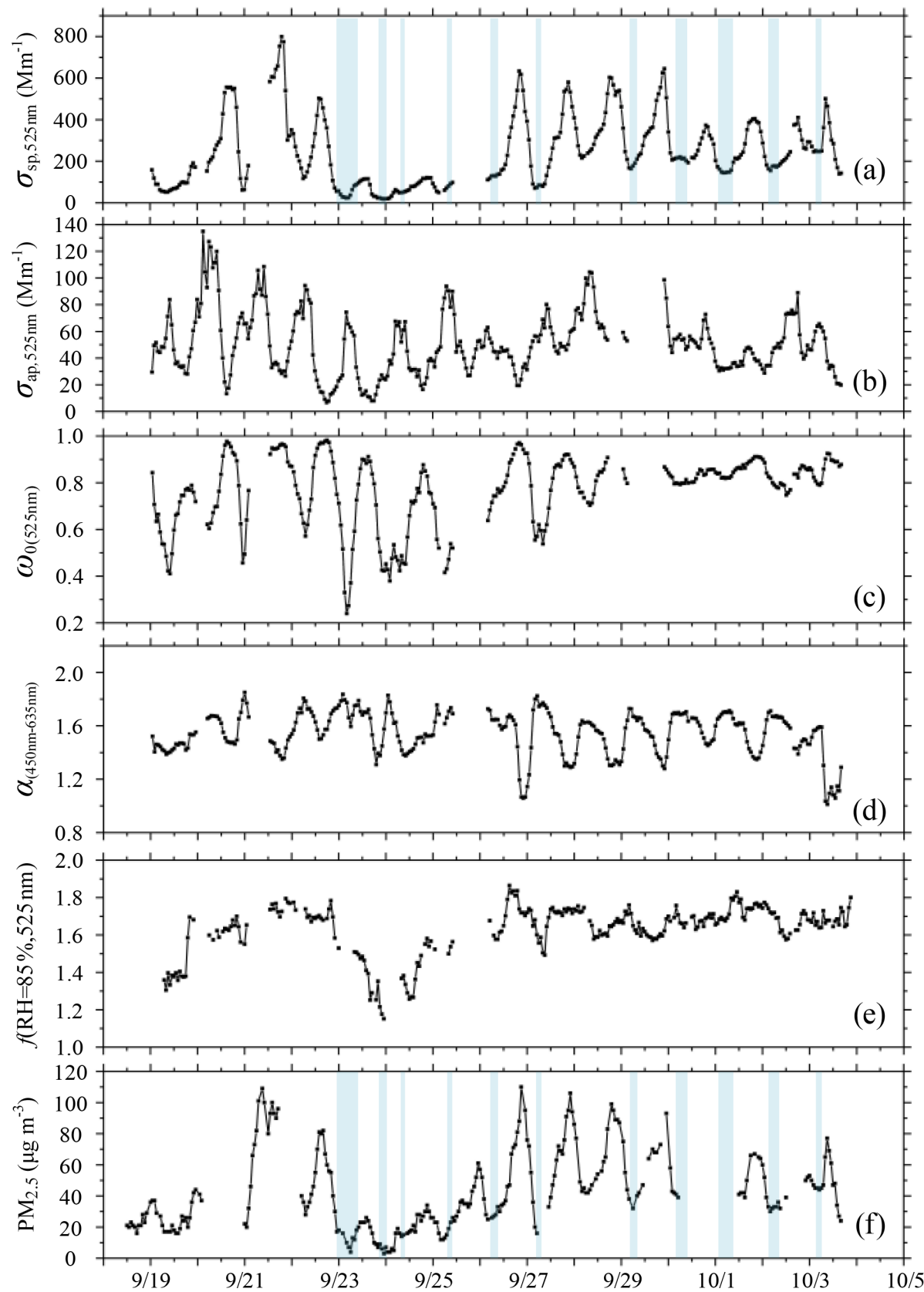

Figure 1. Hourly averaged time series (18 September to 4 October 2019$)$ of the (a) scattering coefficient $\left(\sigma_{\mathrm{sp}, 525 \mathrm{~nm}}\right)$ measured by the dry nephelometer (unit: $\left.\mathrm{Mm}^{-1}\right)$, (b) absorption coefficient $\left(\sigma_{\mathrm{ap}, 525 \mathrm{~nm}}\right.$; unit: $\left.\mathrm{Mm}^{-1}\right)$, (c) single-scattering albedo $\left(\omega_{0}(525 \mathrm{~nm})\right.$, $(\mathbf{d})$ scattering Ångström exponent $\left(\alpha_{(450-635 \mathrm{~nm})}\right)$, (e) particle light scattering enhancement factor at $\mathrm{RH}=85 \%(f(\mathrm{RH}=85 \%, 525 \mathrm{~nm}))$, and (f) mass concentration of $\mathrm{PM}_{2.5}$ (unit: $\mu \mathrm{g} \mathrm{m}^{-3}$ ) measured at the Yizhuang station. The segments of the time series with a blue background represent the occurrence of deliquescence. The timescale is Beijing time (UTC $+8 \mathrm{~h})$. The date in this figure is in the month/day format.

2 October. Organic matter mass fractions were larger than $52 \%$, and inorganic matter mass fractions were generally smaller when $f(\mathrm{RH}=85 \%, 525 \mathrm{~nm})$ was less than 1.40 . However, high values of $f(\mathrm{RH}=85 \%, 525 \mathrm{~nm})$ in this study were often closely correlated with large fractions of water-soluble ions, such as $\mathrm{NO}_{3}^{-}$and $\mathrm{SO}_{4}^{2-}$, in $\mathrm{PM}_{2.5}$. Inorganic matter mass fractions were larger than $53 \%$, and or- ganic matter mass fractions were relatively small when the $f(\mathrm{RH}=85 \%, 525 \mathrm{~nm})$ was greater than 1.70 . The campaign mean \pm standard deviation values of $f(\mathrm{RH}=85 \%, 525 \mathrm{~nm})$ were $1.64 \pm 0.13$ (Table 1 ). Figure $2 \mathrm{c}$ reveals that strongly hygroscopic aerosols with high values of $f(\mathrm{RH}=85 \%$, $525 \mathrm{~nm}$ ) primarily came from the southeast sector. The proportion of secondary inorganics with strong hygroscopic 
Table 1. Average $\sigma_{\mathrm{sp}, 525 \mathrm{~nm}}, \sigma_{\mathrm{ap}, 525 \mathrm{~nm}}, \omega_{0(525 \mathrm{~nm})}, \alpha_{(450-635 \mathrm{~nm})}, f(\mathrm{RH}=85 \%, 525 \mathrm{~nm})$, and $\mathrm{PM}_{2.5}$ mass concentration values at different pollution levels.

\begin{tabular}{|c|c|c|c|c|}
\hline & \multirow{2}{*}{$\begin{array}{r}\text { Entire } \\
\text { observation } \\
\text { period }\end{array}$} & \multicolumn{3}{|c|}{$\mathrm{PM}_{2.5}$ pollution levels $\left(\mu \mathrm{g} \mathrm{m}^{-3}\right)$} \\
\hline & & $\begin{array}{r}\text { Very clean } \\
\left(\mathrm{PM}_{2.5} \leq 35\right)\end{array}$ & $\begin{array}{r}\text { Moderately polluted } \\
\left(35<\mathrm{PM}_{2.5} \leq 75\right)\end{array}$ & $\begin{array}{l}\text { Heavily polluted } \\
\quad\left(\mathrm{PM}_{2.5}>75\right)\end{array}$ \\
\hline$\sigma_{\mathrm{sp}, 525 \mathrm{~nm}}\left(\mathrm{Mm}^{-1}\right)$ & $245 \pm 168$ & $89 \pm 45$ & $279 \pm 93$ & $530 \pm 75$ \\
\hline$\sigma_{\mathrm{ap}, 525 \mathrm{~nm}}\left(\mathrm{Mm}^{-1}\right)$ & $50 \pm 24$ & $43 \pm 21$ & $51 \pm 20$ & $50 \pm 27$ \\
\hline$\omega_{0}(525 \mathrm{~nm})(-)$ & $0.77 \pm 0.15$ & $0.65 \pm 0.16$ & $0.83 \pm 0.08$ & $0.93 \pm 0.04$ \\
\hline$\alpha_{(450-635 \mathrm{~nm})}(-)$ & $1.55 \pm 0.16$ & $1.58 \pm 0.15$ & $1.54 \pm 0.15$ & $1.33 \pm 0.13$ \\
\hline$f(\mathrm{RH}=85 \%, 525 \mathrm{~nm})(-)$ & $1.64 \pm 0.13$ & $1.49 \pm 0.16$ & $1.70 \pm 0.06$ & $1.71 \pm 0.05$ \\
\hline $\mathrm{PM}_{2.5}\left(\mu \mathrm{g} \mathrm{m}^{-3}\right)$ & $44 \pm 25$ & $22 \pm 9$ & $51 \pm 12$ & $90 \pm 9$ \\
\hline
\end{tabular}
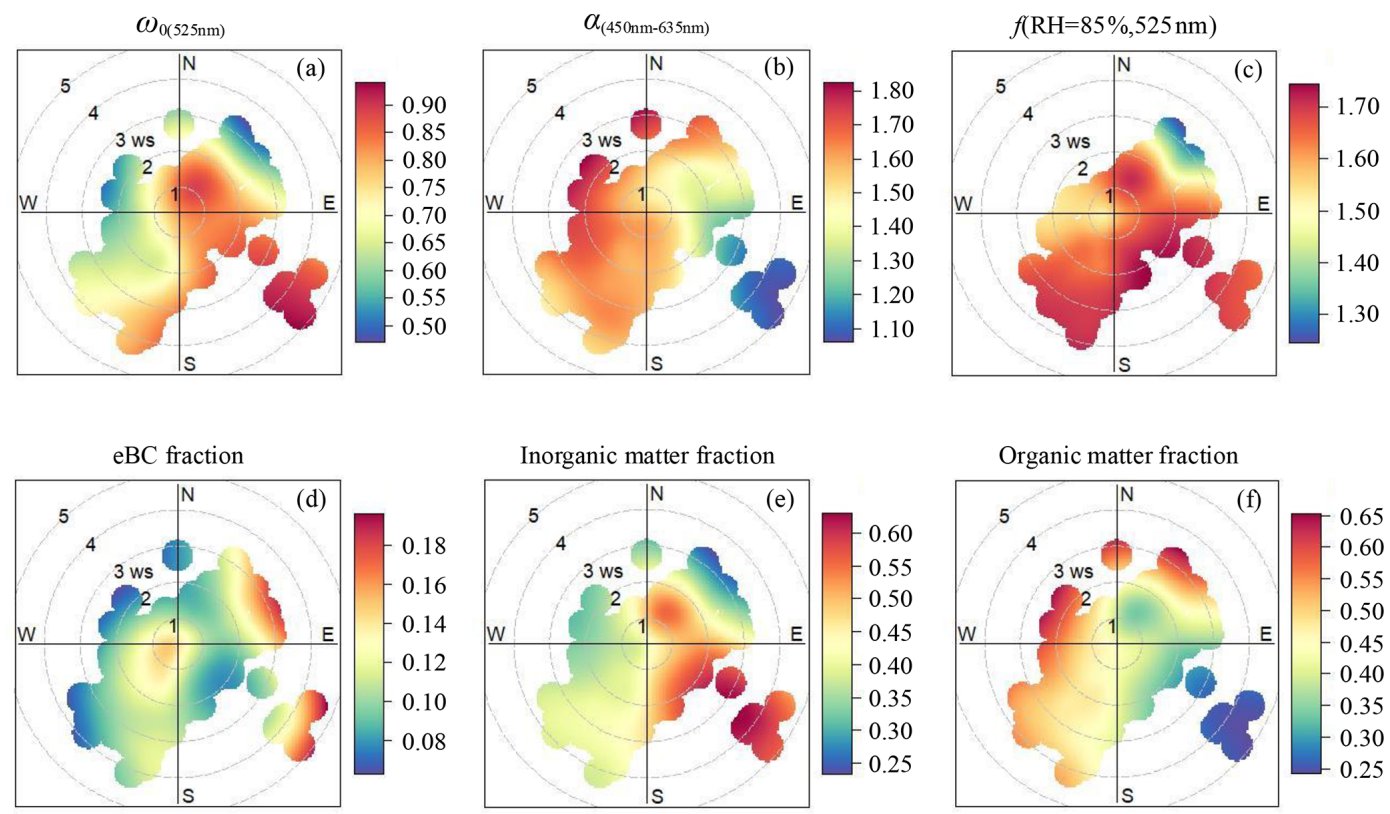

Figure 2. Wind dependence of (a) the single-scattering albedo $\left(\omega_{0}(525 \mathrm{~nm})\right.$, (b) the scattering Ångström exponent $\left(\alpha_{(450-635 \mathrm{~mm})}\right),(\mathbf{c})$ the particle light scattering enhancement factor at $\mathrm{RH}=85 \%(f(\mathrm{RH}=85 \%, 525 \mathrm{~nm}))$, (d) the mass fraction of eBC, (e) the mass fraction of inorganic matter, and (f) the mass fraction of organic matter. The circular contours show the average change in wind speed and direction.

abilities in aerosols from this direction was high, while the proportion of organic matter with weak hygroscopic abilities was low (Fig. 2e-f). Figure 2d indicates that the mass fraction of eBC with weak hygroscopicity was slightly low in the southeast sector when wind speeds were lower than $4 \mathrm{~m} \mathrm{~s}^{-1}$. However, when wind speeds were higher than $4 \mathrm{~m} \mathrm{~s}^{-1}$, the mass fraction of eBC was relatively high in this direction. Of all data associated with southeast winds, only three cases were identified with wind speeds higher than $4 \mathrm{~m} \mathrm{~s}^{-1}$, likely winds of short duration so not representative. In the northeast direction, high values of $f(\mathrm{RH}=85 \%, 525 \mathrm{~nm})$ occurred when the wind speed was lower than $2 \mathrm{~m} \mathrm{~s}^{-1}$. The hygroscopic capacity of aerosols also weakened as the wind speed increased (Fig. 2c). The proportion of secondary inorganics with strong hygroscopicity decreased with increasing wind speed (Fig. 2e), while the proportion of substances with weak hygroscopicity, such as organic matter and $\mathrm{eBC}$, increased with increasing northeasterly wind speeds (Fig. 2d, f). Furthermore, aerosols from the southwest and southern sectors within the wind-speed range of 2 to $4 \mathrm{~m} \mathrm{~s}^{-1}$ had higher scattering enhancement factors (Fig. 2c) mainly because of the deliquescence of sulfates in the ambient aerosols. The specific reasons are explained in detail in Sect. 3.3. Figure S5 shows that apart from the lower values (10th percentile values in Table S1), a small wavelength dependence in scattering enhancement factor is found in all other percentiles, with a stronger wavelength dependence for high values of $f(\mathrm{RH}=85 \%)$. Zieger et al. (2014) and Zhang et al. (2015) obtained similar results for Melpitz, Germany, and Lin'an, China, respectively.

Figure S6a to $b$ show the time series of mass concentrations and mass fractions, respectively, of submicron aerosols, 
i.e., organic matter, nitrate, sulfate, ammonium, chloride, and eBC in $\mathrm{PM}_{2.5}$. The rightmost pie chart in Fig. S6c shows that during the entire observation period, organic matter was the major component of $\mathrm{PM}_{2.5}$, accounting for $39 \%$. Nitrate and sulfate comprised similar fractions of $\mathrm{PM}_{2.5}$, i.e., $21 \%$ and $19 \%$, respectively. The mass fraction of nitrate was slightly larger than that of sulfate. Note that eBC accounted for $11 \%$ of $\mathrm{PM}_{2.5}$ during the entire measurement period. Two special periods were noted. One started in the afternoon of 21 September and ended late morning on 22 September (Sect. I in Fig. S6a). First, the concentrations of all chemical components during this period were high. As shown by the leftmost pie chart in Fig. S6c, the mass fraction of nitrate was the largest, accounting for $33 \%$ of the total mass fraction on average, lasting a long time. However, compared with the proportion of inorganic matter $(66 \%)$, the mass fraction of organic matter was much smaller, accounting for $27 \%$ of the total mass fraction. Accordingly, the $f(\mathrm{RH}=85 \%, 525 \mathrm{~nm})$ remained at a high level during this period (Fig. 1e). The other special period was on 24 September (Sect. II in Fig. S6a). The mass concentrations of all aerosol species remained low. The middle pie chart in Fig. S6c clearly demonstrates that organic matter comprised the main fraction of $\mathrm{PM}_{2.5}$, accounting for $55 \%$ on average, followed by eBC. The fraction of nitrate was especially small during this clean period. The fraction of sulfate, accounting for $16 \%$, was 4 times that of nitrate, which was an advantage for deliquescence in this period (discussed in more detail in Sect. 3.3). Although the proportions of hydrophobic organic matter and $\mathrm{eBC}$ in aerosols during this period was very high, $f(\mathrm{RH}=85 \%, 525 \mathrm{~nm})$ was not the lowest during the whole observation period because the $f(\mathrm{RH}=85 \%, 525 \mathrm{~nm})$ of deliquescence was higher than the normal value. Note that $\mathrm{PM}_{2.5}$ aerosols at the observatory in suburban Beijing were faintly acidic during the observation period (Fig. S7), benefitting the hygroscopic enhancement of ambient aerosols.

\subsection{The relationship between the particle light scattering enhancement factor and aerosol chemical composition}

Figure 3 displays $f(\mathrm{RH}=85 \%, 525 \mathrm{~nm})$ as a function of the main chemical component mass fractions. The total aerosol mass concentration is the sum of mass concentrations of all chemical constituents, including nitrate, sulfate, ammonium, chloride, and organic matter measured by the ACSM and $\mathrm{eBC}$ retrieved by the AE33. The mass fractions of individual chemical components were calculated by respectively dividing the mass concentrations of sulfate, nitrate, ammonium, and $\mathrm{eBC}$ by the sum of all chemical constituents. The $f(\mathrm{RH}=85 \%, 525 \mathrm{~nm})$ and $\mathrm{eBC}$ were negatively correlated, with a correlation coefficient $R$ equal to -0.62 (Fig. 3d). A positive correlation is seen between $f(\mathrm{RH}=85 \%, 525 \mathrm{~nm})$ and the three other inorganic substances' mass fractions because of their hygroscopic characteristics. The ammonium mass fraction had the strongest positive correlation $(R=$ $0.78)$ with $f(\mathrm{RH}=85 \%, 525 \mathrm{~nm})$ (Fig. 3c). The reason is that ammonium is the common positive ion of $\left(\mathrm{NH}_{4}\right)_{2} \mathrm{SO}_{4}$ and $\mathrm{NH}_{4} \mathrm{NO}_{3}$, two major salts of inorganic substances in aerosols. The relationship between $f(\mathrm{RH}=85 \%, 525 \mathrm{~nm})$ and ammonium is thus similar to that between $f(\mathrm{RH}=85 \%$, $525 \mathrm{~nm}$ ) and inorganic content. The hygroscopic properties were different for $\mathrm{NH}_{4} \mathrm{NO}_{3}$ and $\left(\mathrm{NH}_{4}\right)_{2} \mathrm{SO}_{4}$. As expected, $f(\mathrm{RH}=85 \%, 525 \mathrm{~nm})$ was positively correlated with the sum of the nitrate and sulfate mass fractions (slope $=1.03$ and $R=0.79$; Fig. S8), similar to the correlation between $f(\mathrm{RH}=85 \%, 525 \mathrm{~nm})$ and the inorganic mass fraction. $\mathrm{Wu}$ et al. (2017) and Zieger et al. (2014) reported similar results.

Figure 4 shows $f(\mathrm{RH}=85 \%, 525 \mathrm{~nm})$ as a function of the mass fractions of organic and inorganic matter. The mass fractions of inorganic and organic matter were respectively calculated by dividing inorganic matter (the sum of nitrate, sulfate, ammonium, and chloride) and organic matter mass concentrations by the total mass concentration. The inorganic mass fraction was positively correlated with $f(\mathrm{RH}=85 \%$, $525 \mathrm{~nm}$ ) because of the high hygroscopicity of the inorganic compounds, while organic substances were negatively correlated with $f(\mathrm{RH}=85 \%, 525 \mathrm{~nm})$ because of their lower hygroscopicity (P. Zhao et al., 2019). Both correlation coefficients were similar to those from previous studies (Zieger et al., 2014; Zhang et al., 2015; Wu et al., 2017). Also, the absolute values of both the slopes and corresponding standard deviations found here $(0.80 \pm 0.04$ and $1.00 \pm 0.06$ for $f(\mathrm{RH}=85 \%, 525 \mathrm{~nm})$ as a function of inorganic and organic matter mass fractions, respectively) were similar to those reported in Lin' an, China ( $0.96 \pm 0.02$ and $1.20 \pm 0.04$, respectively; Zhang et al., 2015), but much lower than those observed in Melpitz, Germany (2.2 \pm 0.078 and 3.1 \pm 0.1 , respectively; Zieger et al., 2014). This might be because the $f(\mathrm{RH}=85 \%, 525 \mathrm{~nm})$ measured in Melpitz, Germany, was much higher than that in Lin'an and Beijing. Ambient aerosols in Melpitz, Germany, were partially affected by sea salt, like sodium chloride, transported from the North Sea and being highly hygroscopic. Marine aerosols have a higher hygroscopicity than aerosols influenced more by human activity.

Distinguishing between data points below and above the $40 \%$ organic mass fraction level in Fig. 4, the absolute values of the linear regression slope and $R$ for data below $40 \%$ were lower than those for data above $40 \%$. However, for the inorganic mass fraction (left panels of Fig. 4), the absolute values of the linear regression slope and $R$ for data below $40 \%$ were higher than those for data above $40 \%$. This indicates that the positive correlation between $f(\mathrm{RH}=85 \%, 525 \mathrm{~nm})$ and the inorganic matter mass fraction was very strong when inorganic matter mass fractions were smaller than $40 \%$. However, when inorganic matter mass fractions were larger than $40 \%$, the increasing tendency in $f(\mathrm{RH}=85 \%, 525 \mathrm{~nm})$ as the proportion of inorganic matter increased slowly decreased. Inversely, the neg- 

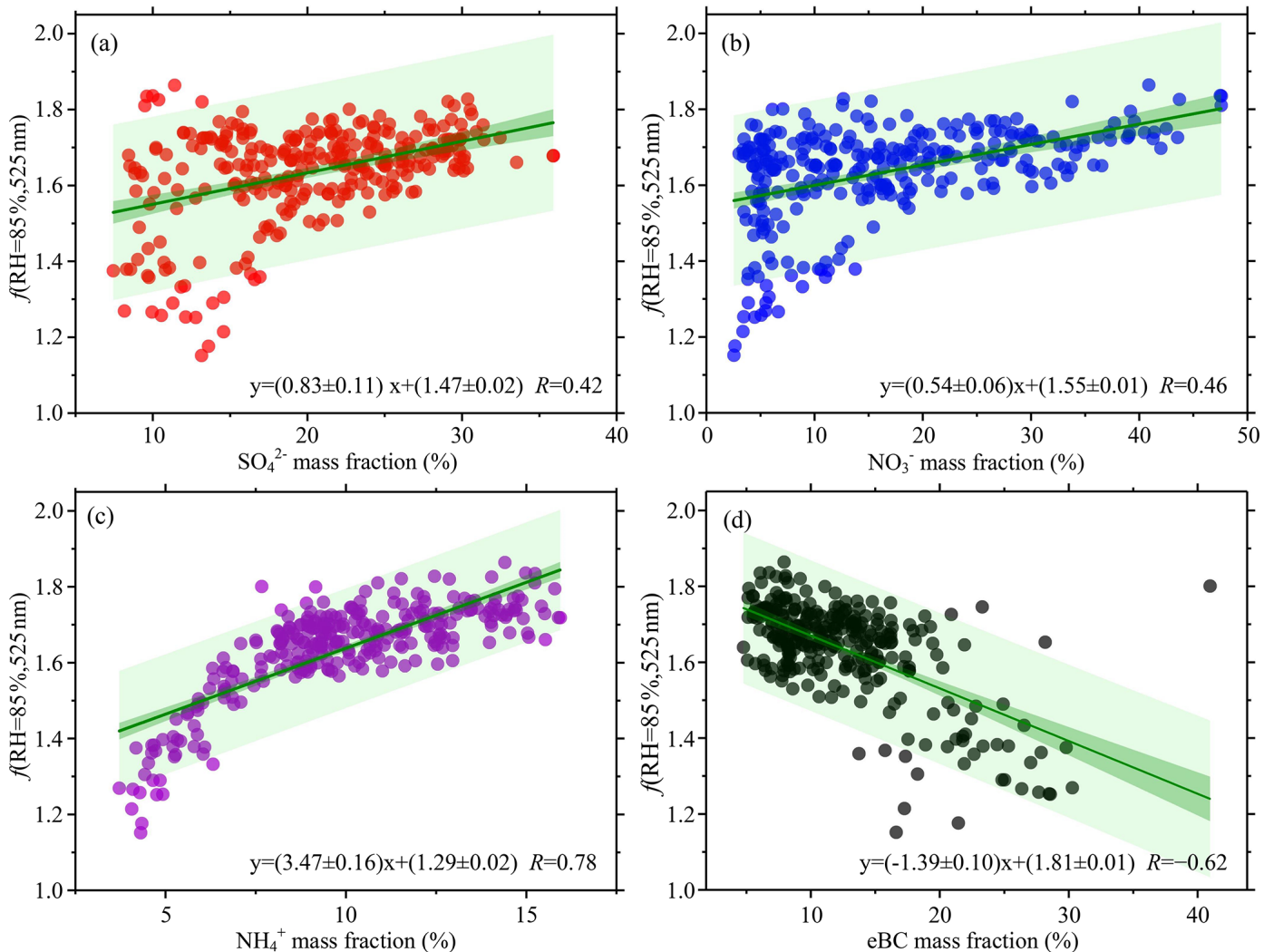

Figure 3. The particle light scattering enhancement factor $f(\mathrm{RH}=85 \%, 525 \mathrm{~nm})$ as a function of different aerosol chemical component mass fractions measured by the ACSM and the AE33: (a) sulfate $\left(\mathrm{SO}_{4}^{2-}\right)$ mass fraction, (b) nitrate $\left(\mathrm{NO}_{3}^{-}\right)$mass fraction, (c) ammonium $\left(\mathrm{NH}_{4}^{+}\right)$mass fraction, and (d) the equivalent black carbon (eBC) mass fraction. Solid green lines represent bivariate linear regressions. The dark-green shaded areas denote $95 \%$ confidence levels, and the light-green shaded areas show the $95 \%$ prediction bands for the fits. The linear regression function and the Pearson's correlation coefficient $(R)$ are given in each panel.

ative correlation between $f(\mathrm{RH}=85 \%, 525 \mathrm{~nm})$ and the organic matter mass fraction was slightly weak when organic matter mass fractions were smaller than $40 \%$. When organic matter mass fractions were larger than $40 \%$, the decreasing tendency in $f(\mathrm{RH}=85 \%, 525 \mathrm{~nm})$ as the proportion of organic matter decreased became more robust. There may be several reasons for this phenomenon. First, particle size may be one of the most important factors to explain this. For particles with strong hygroscopicity, if their particle number size distribution tends towards large particle sizes, their hygroscopic growth ability may be similar to that of smaller particles with weak hygroscopicity (Zieger et al., 2010, 2013; Wang et al., 2017, 2018). On the one hand, the $f(\mathrm{RH})$ of particles usually decreases with increasing particle size (Zieger et al., 2013), resulting in a lower $f(\mathrm{RH})$ for larger particles. On the other hand, the larger particles' amplification effect of scattering cross section because of hygroscopic growth is weaker than that of smaller particles (Wu et al., 2017). It may be that when there is a high proportion of inorganic matter and a low proportion of organic matter, the inorganic matter is mainly composed of relatively large particles. It is possible that the $f(\mathrm{RH}=85 \%, 525 \mathrm{~nm})$ of aerosols with a high level of inorganic matter and a low level of organic matter is not as high as expected due to the compensating effect between the size and the chemical composition of aerosol. Second, the higher mass concentration of ambient aerosols is maybe another reason. Overall, when the mass concentration of inorganic substances was less than $40 \%$, the total mass concentration of aerosols was relatively low in this experiment. When the proportion of inorganic matter was higher than $40 \%$, the total mass concentration of aerosols was high, with a clear inhibiting effect of high aerosol mass concentration to the $f(\mathrm{RH}=85 \%, 525 \mathrm{~nm})$ (Fig. 4e). Finally, it is also possible that when the proportion of inorganic matter is very high, aerosols absorb too much water vapor, leading to insufficient ambient water vapor.

The green dots in Fig. S9a and b represent deliquescence. The range of inorganic mass fraction in these deliquescent processes was from $30 \%$ to $50 \%$, and the range of organic mass fraction was from $40 \%$ to $60 \%$. A comparison between Fig. $4 \mathrm{a}$ and $\mathrm{c}$ and $\mathrm{b}$ and $\mathrm{d}$ shows that the proportion of sulfate in the total aerosol was much higher than that of nitrate for these deliquescent processes. Meanwhile, the $f(\mathrm{RH}=85 \%$, $525 \mathrm{~nm}$ ) of these deliquescent processes were all above the 

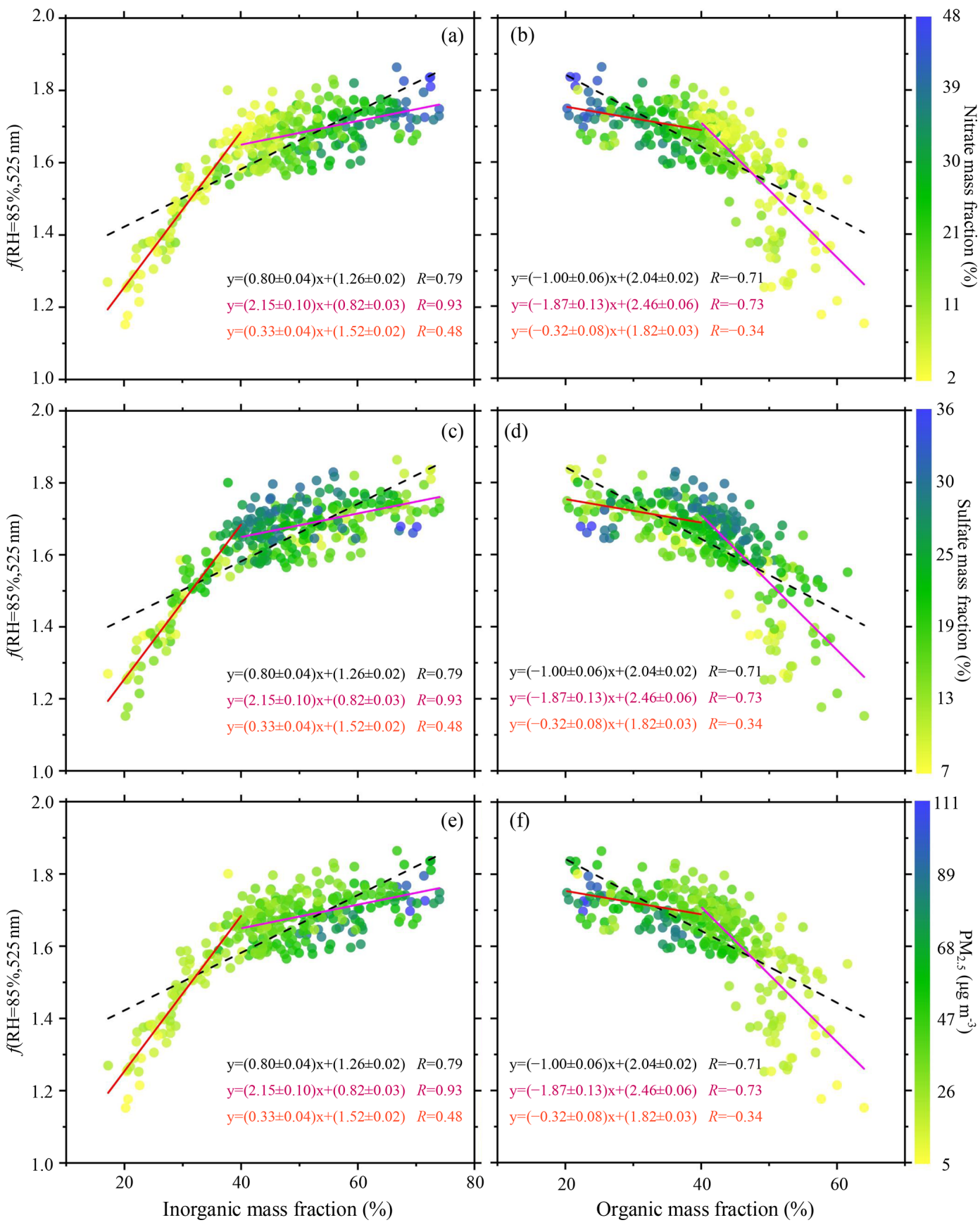

Figure 4. The particle light scattering enhancement factor $f(\mathrm{RH}=85 \%, 525 \mathrm{~nm})$ as a function of organic matter mass fraction and inorganic matter mass fraction measured by the ACSM and the AE33: $f(\mathrm{RH}=85 \%, 525 \mathrm{~nm})$ as a function of (a) inorganic matter mass fraction and (b) organic matter mass fraction colored by the nitrate mass fraction; $f(\mathrm{RH}=85 \%, 525 \mathrm{~nm})$ as a function of (c) inorganic matter mass fraction and (d) organic matter mass fraction colored by the sulfate mass fraction; and $f(\mathrm{RH}=85 \%, 525 \mathrm{~nm})$ as a function of (e) inorganic matter mass fraction and (f) organic matter mass fraction colored by the mass concentration of $\mathrm{PM}_{2.5}$. Dotted black lines denote bivariate linear regressions. The red and magenta lines are the best-fit linear regression lines through data points associated with mass fractions smaller than $40 \%$ and larger than $40 \%$, respectively. The linear regression functions and the Pearson's correlation coefficients $(R)$ are given in each panel. 
best-fit regression lines. This demonstrates that the scattering enhancement factor at $85 \%$ RH of deliquescence was generally higher than that of the non-deliquescent process. Kuang et al. (2016) also drew the same conclusion.

Comparing Fig. 4a and c, as the proportion of inorganic salts in the total aerosol increased, the proportion of nitrate in the total aerosol also increased, unlike the proportion of sulfate in the total aerosol. This demonstrates that nitrate played a primary role in affecting aerosol hygroscopic enhancement during the study period in Beijing. To further compare the correlation between sulfate and the hygroscopicity of aerosols with that between nitrate and the hygroscopicity of aerosols, an ion-pairing scheme was used to calculate the mass concentrations of $\left(\mathrm{NH}_{4}\right)_{2} \mathrm{SO}_{4}, \mathrm{NH}_{4} \mathrm{HSO}_{4}$, and $\mathrm{NH}_{4} \mathrm{NO}_{3}$ in aerosols on the basis of the molar numbers of all ions (Gysel et al., 2007). The following is the ion-pairing scheme:

$$
\begin{aligned}
& n_{\mathrm{NH}_{4} \mathrm{NO}_{3}}=n_{\mathrm{NO}_{3}^{-}}, \\
& n_{\mathrm{H}_{2} \mathrm{SO}_{4}}=\max \left(0, n_{\mathrm{SO}_{4}^{2-}}-n_{\mathrm{NH}_{4}^{+}}+n_{\mathrm{NO}_{3}^{-}}\right), \\
& n_{\mathrm{NH}_{4} \mathrm{HSO}_{4}}=\min \left(2 n_{\mathrm{SO}_{4}^{2-}}-n_{\mathrm{NH}_{4}^{+}}+n_{\mathrm{NO}_{3}^{-}} n_{\mathrm{NH}_{4}^{+}}-n_{\mathrm{NO}_{3}^{-}}\right), \\
& n_{\left(\mathrm{NH}_{4}\right)_{2} \mathrm{SO}_{4}}=\max \left(n_{\mathrm{NH}_{4}^{+}}-n_{\mathrm{NO}_{3}^{-}}-n_{\mathrm{SO}_{4}^{2-}}, 0\right), \\
& n_{\mathrm{HNO}_{3}}=0,
\end{aligned}
$$

where $n$ denotes the number of moles. Figure 5 a to $\mathrm{c}$ show $\gamma$ as a function of $F_{\text {org }}$ (Eq. 6), where $C_{\mathrm{i}}$ represents the sum of $\left(\mathrm{NH}_{4}\right)_{2} \mathrm{SO}_{4}$ and $\mathrm{NH}_{4} \mathrm{HSO}_{4}, \mathrm{NH}_{4} \mathrm{NO}_{3}$ and the sum of $\left(\mathrm{NH}_{4}\right)_{2} \mathrm{SO}_{4}, \mathrm{NH}_{4} \mathrm{HSO}_{4}$, and $\mathrm{NH}_{4} \mathrm{NO}_{3}$ mass concentrations, respectively. Overall, $\gamma$ and $F_{\text {org }}$ are negatively correlated. The coefficient of determination between $\gamma$ and $F_{\text {org }}$ $\left(\mathrm{Org} /\left(\mathrm{Org}+\mathrm{NH}_{4} \mathrm{NO}_{3}\right)\right)($ Fig. $5 b)$ was higher than that between $\gamma$ and $F_{\text {org }}\left(\mathrm{Org} /\left(\mathrm{Org}+\left(\mathrm{NH}_{4}\right)_{2} \mathrm{SO}_{4}+\mathrm{NH}_{4} \mathrm{HSO}_{4}\right)\right)$ (Fig. 5a). The coefficient of determination between $\gamma$ and $F_{\text {org }} \quad\left(\mathrm{Org} /\left(\mathrm{Org}+\left(\mathrm{NH}_{4}\right)_{2} \mathrm{SO}_{4}+\mathrm{NH}_{4} \mathrm{HSO}_{4}+\mathrm{NH}_{4} \mathrm{NO}_{3}\right)\right.$ was the highest (Fig. 5c). This suggests that nitrate played a more significant role than sulfate in affecting aerosol hygroscopic growth during the study period in Beijing. In recent years, the Chinese government has made more efforts to control $\mathrm{SO}_{2}$ emissions (Zhang et al., 2019), e.g., adjusting and optimizing industrial capacities. Clean fuels have also been promoted in the residential sector, with trials for using clean energy in heating in northern China carried out in all " $2+26$ " cities and in the Fenhe River and Weihe River plains. In addition, compliance with industrial emission standards has been strengthened. Desulfurization technology has been also applied to many heavy industrial facilities. However, China has many small-scale manufacturing enterprises, so it is much more difficult to regulate $\mathrm{NO}_{x}$ emissions than $\mathrm{SO}_{2}$ emissions. H. Li et al. (2019) have reported that emissions of $\mathrm{SO}_{2}$ and $\mathrm{NO}_{x}$ in 2017 dropped by $79.9 \%$ and $38.1 \%$, respectively, from 2014 levels in Beijing, China. In 2020, $\mathrm{SO}_{2}$ and primary $\mathrm{PM}_{2.5}$ emissions dropped to 1 million tons, while $\mathrm{NO}_{x}$ and volatile organic compound emissions were still 10 million tons. As a result, the decrease in $\mathrm{SO}_{2}$ resulted in an increase in $\mathrm{NH}_{4} \mathrm{NO}_{3}$ (Morgan et al., 2010; $\mathrm{Xu}$ et al., 2019; Zhang et al., 2019; H. Li et al., 2019). Several previous studies focusing on megacities like Shanghai and Beijing have all suggested that the increase in nitrate mass concentration played an important role in enhancing the water content of submicron aerosols and reducing visibility under high RH conditions (Sun et al., 2012; Shi et al., 2014; Zhang et al., 2015).

Figure $\mathrm{S} 10 \mathrm{a}$ shows the scatterplot of $\gamma$ as a function of $F_{\text {org }}\left(\mathrm{Org} /\left(\mathrm{Org}+\left(\mathrm{NH}_{4}\right)_{2} \mathrm{SO}_{4}+\mathrm{NH}_{4} \mathrm{HSO}_{4}+\mathrm{NH}_{4} \mathrm{NO}_{3}\right)\right.$, where the color of the data points represents the $\mathrm{SO}_{4}^{2-} /\left(\mathrm{SO}_{4}^{2-}+\mathrm{SO}_{2}\right)$ molar ratio. This molar ratio indicates the relative age of aerosols (Quinn et al., 2005) because by gas- and aqueous-phase oxidation processes, $\mathrm{SO}_{2}$ will convert to $\mathrm{SO}_{4}^{2-}$. The molar ratio of more aged aerosols is high due to the sufficient time for the conversion. The $\mathrm{SO}_{4}^{2-} /\left(\mathrm{SO}_{4}^{2-}+\mathrm{SO}_{2}\right)$ molar ratio is low for younger aerosols. The figure shows that high $\gamma$ corresponded to high $\mathrm{SO}_{4}^{2-} /\left(\mathrm{SO}_{4}^{2-}+\mathrm{SO}_{2}\right)$ molar ratios with a low organic matter content, while low $\gamma$ corresponded to low $\mathrm{SO}_{4}^{2-} /\left(\mathrm{SO}_{4}^{2-}+\mathrm{SO}_{2}\right)$ molar ratios with a high organic matter content, consistent with results reported by Quinn et al. (2005) and Zhang et al. (2015). This demonstrates that the hygroscopicity of aged aerosols is higher than that of younger aerosols. Figure S10b shows that the aerosol scattering coefficients $\log _{10}\left(\sigma_{\mathrm{sp}}\right)$ were relatively low when $\gamma$ was low and the organic matter mass fraction was large. On the contrary, $\log _{10}\left(\sigma_{\mathrm{sp}}\right)$ was high when $\gamma$ was high, and the organic mass fraction was small, with a relatively large variation.

\subsection{Deliquescence of ambient aerosols}

Figure 6a shows the time series of $\eta$, with the color of the data points representing the ratio of $\mathrm{SO}_{4}^{2-}$ mass concentration to $\mathrm{NO}_{3}^{-}$mass concentration. Figure $6 \mathrm{~b}$ and $\mathrm{c}$ show the time series of wind direction and wind speed and ambient temperature and RH, respectively. Overall, deliquescence often occurred under high ambient temperature and low RH conditions (Fig. 6c). It also more easily occurred when winds with low speeds came from the south or southwest (Fig. 6b). High values of $\eta$ usually occurred when the ratio of $\mathrm{SO}_{4}^{2-}$ mass concentration to $\mathrm{NO}_{3}^{-}$mass concentration was high (mostly higher than $\sim 4$ ). Figure 7 a shows a relatively strong correlation between $\eta$ and the ratio of $\mathrm{SO}_{4}^{2-}$ mass concentration to $\mathrm{NO}_{3}^{-}$mass concentration $(R=0.62)$. The blue dots represent the hysteresis index $(\eta>0.4)$ of deliquescence, showing that the corresponding ratios of $\mathrm{SO}_{4}^{2-}$ mass concentration to $\mathrm{NO}_{3}^{-}$mass concentration were high (mostly higher than $\sim 4$ ). The red dots represent the hysteresis index of nondeliquescent processes, showing that the corresponding ratios of $\mathrm{SO}_{4}^{2-}$ mass concentration to $\mathrm{NO}_{3}^{-}$mass concentration were generally less than 4 . Because $\mathrm{PM}_{2.5}$ mass concentrations were extremely low on 24 September 2019, data were 

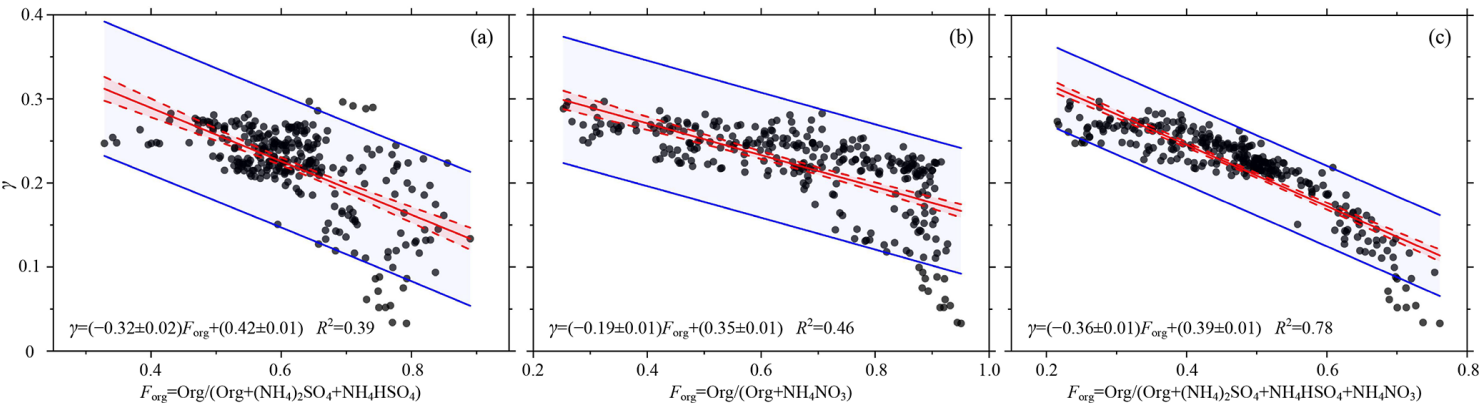

Figure 5. Scatter plots of $\gamma$ as a function of the relative amounts of organic and inorganic matter $\left(F_{\text {org }}\right)$ : (a) $F_{\text {org }}=\mathrm{Org} /\left(\mathrm{Org}+\left(\mathrm{NH}_{4}\right)_{2} \mathrm{SO}_{4}+\right.$ $\left.\mathrm{NH}_{4} \mathrm{HSO}_{4}\right)$, (b) $F_{\text {org }}=\mathrm{Org} /\left(\mathrm{Org}+\mathrm{NH}_{4} \mathrm{NO}_{3}\right)$, and (c) $F_{\text {org }}=\mathrm{Org} /\left(\mathrm{Org}+\left(\mathrm{NH}_{4}\right)_{2} \mathrm{SO}_{4}+\mathrm{NH}_{4} \mathrm{HSO}_{4}+\mathrm{NH}_{4} \mathrm{NO}_{3}\right)$. Solid red lines show the linear fits, dotted red lines represent the $95 \%$ confidence levels, and solid blue lines represent the $95 \%$ prediction bands for the fit. The linear regression function and the squared Pearson's correlation coefficient $\left(R^{2}\right)$ are given in each panel.

noisy then, and the system error was relatively large (green dots). When these cases of large systematic errors were eliminated, the correlation between $\eta$ and the ratio of $\mathrm{SO}_{4}^{2-}$ to $\mathrm{NO}_{3}^{-}$mass concentration increased $(R=0.69)$. In the North China Plain, Kuang et al. (2016) also observed a similar deliquescent phenomenon associated with $\left(\mathrm{NH}_{4}\right)_{2} \mathrm{SO}_{4}$, while in Ny-Ålesund, Norway, this deliquescent phenomenon was related to sea salt (Zieger et al., 2010).

According to observational results, there are two environmental conditions of consequence for ambient aerosol deliquescence:

\section{1. high ambient temperature and low ambient RH}

2. relatively good air quality and solar illumination.

Concerning the first condition, Cheung et al. (2015) proposed an indicator describing the neutralization extent of aerosols, i.e., the molar ratio, $\mathrm{MR}=\left(\mathrm{NH}_{4}^{+}-\mathrm{NO}_{3}^{-}\right) / \mathrm{SO}_{4}^{2-}$. The MR value of the non-deliquescent process was always the lowest in their study. Their results indicate that when the nitrate content of ambient aerosols was slightly high, and the sulfate content was low, aerosol particles did not exhibit deliquescence resulting from acidic sulfate. Here, only when the mass concentration ratio of sulfate to nitrate was high (mostly higher than $\sim 4$ ) did ambient aerosol particles exhibit deliquescence. Figure $8 \mathrm{a}$ and $\mathrm{b}$ illustrate the diurnal variations in nitrate, along with ammonium and sulfate. Both the mass concentration and mass fraction of nitrate reached their largest and smallest values in the early morning and in the afternoon, respectively. It was closely correlated with the diurnal variation in ambient temperature and $\mathrm{RH}$, where $\mathrm{RH}$ gradually rose as the temperature gradually decreased from the late afternoon to the early morning of the next day, followed by a reversal of the trend into the late afternoon of the next day (Fig. 6c). Morino et al. (2006) and Wang et al. (2009) found that the formation of nitrate requires low temperatures and high RH, conditions favorable for the conversion of gaseous nitric acid to solid-phase nitrate. Ambient aerosol deliquescence is thus closely related to the envi- ronmental conditions of high temperature and low humidity. Note that secondary sulfates are usually produced by photochemical reactions so that the sulfate content of aerosols gradually accumulates from late morning to late afternoon (Huang et al., 2010; Sun et al., 2012). Generally speaking, the ambient temperature was higher, and the humidity was lower in the afternoon, so high values of $\mathrm{SO}_{4}^{2-} / \mathrm{NO}_{3}^{-}$mostly occurred in the afternoon. This may also explain why the deliquescent cycle occurred most frequently in the afternoon, as shown in Fig. 7b.

The blue-shaded zones in Fig. 1a and $\mathrm{f}$ show that deliquescence usually occurred when the air quality was good. To better explain this phenomenon, the observation period was divided into a very clean period $\left(\mathrm{PM}_{2.5} \leq 35 \mu \mathrm{g} \mathrm{m}^{-3}\right)$ and a moderately polluted period $\left(35 \mu \mathrm{g} \mathrm{m}^{-3}<\mathrm{PM}_{2.5} \leq 75 \mu \mathrm{g} \mathrm{m}^{-3}\right)$. The difference between $f(\mathrm{RH}=85 \%, 525 \mathrm{~nm})$ and $f(\mathrm{RH}=80 \%, 525 \mathrm{~nm})$, i.e., $\mathrm{DF}$, or $f(\mathrm{RH}=85 \%, 525 \mathrm{~nm})$ minus $f(\mathrm{RH}=80 \%, 525 \mathrm{~nm})$, was calculated. Figure $8 \mathrm{c}$ shows the values of DF during a very clean period and a moderately polluted period. The DF of deliquescence is larger than that of non-deliquescence because the $f(\mathrm{RH})$ of deliquescence jumps suddenly as the $\mathrm{RH}$ increases from $80 \%$ to $85 \%$, while the $f(\mathrm{RH})$ of nondeliquescence increases smoothly as the RH increases. The values of the particle light scattering enhancement factor at high RH for deliquescent processes were usually higher than those for non-deliquescent processes, consistent with the strong hygroscopicity of $\left(\mathrm{NH}_{4}\right)_{2} \mathrm{SO}_{4}$. Figure $8 \mathrm{c}$ shows that the diurnal range of DF during the clean period was larger than that during the moderately polluted period. In particular, from late morning to late afternoon, the DF during the clean period was much higher than that during the moderately polluted period. Figure $8 \mathrm{~d}$ shows the diurnal variation in $\mathrm{SO}_{4}^{2-} / \mathrm{NO}_{3}^{-}$. The ratio $\mathrm{SO}_{4}^{2-} / \mathrm{NO}_{3}^{-}$during the clean period was higher than that during the moderately polluted period, especially from late morning to late afternoon. Overall, good air quality and solar illumination were conducive to photochemical reactions so that more secondary sulfate 

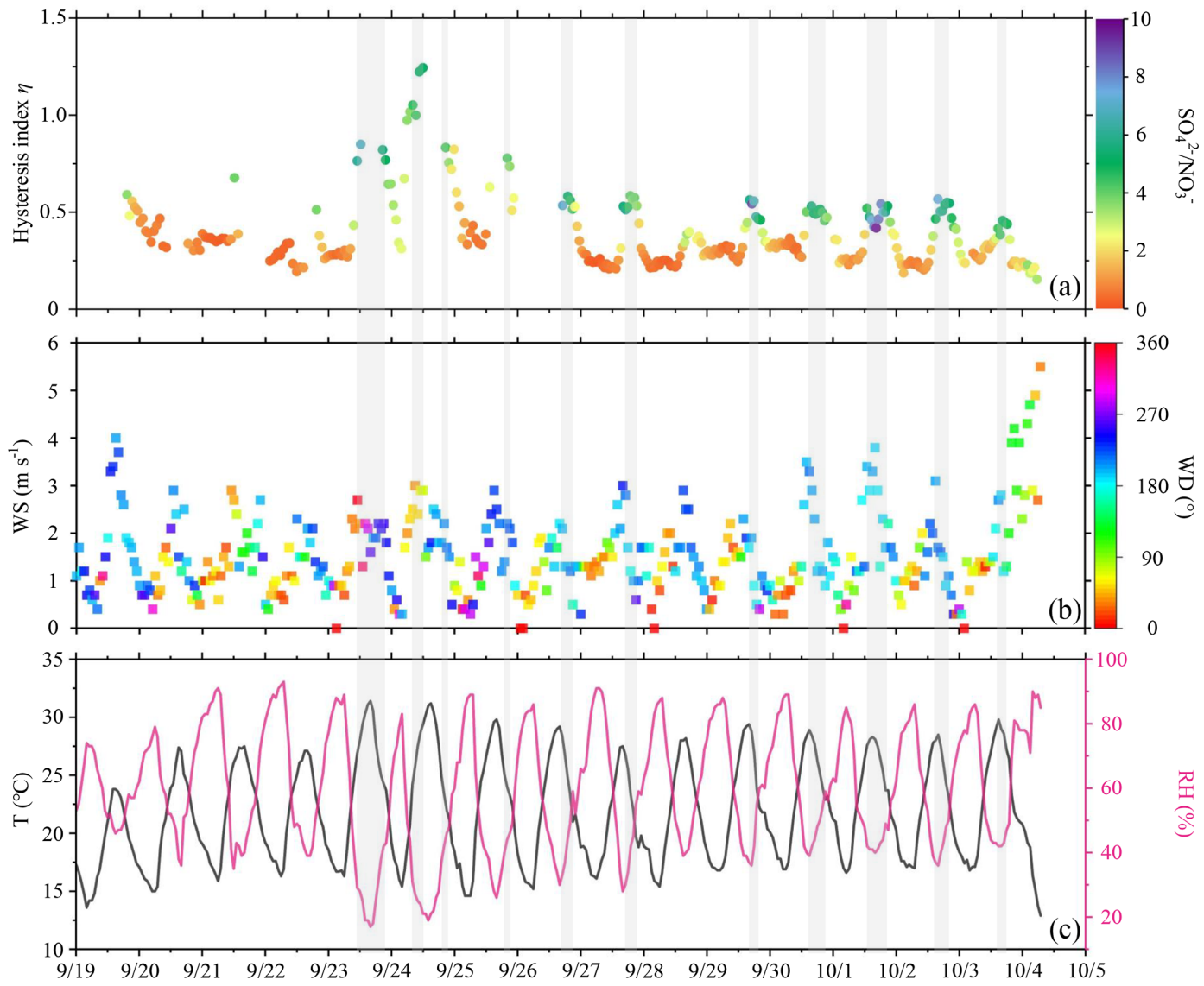

Figure 6. Time series of (a) hysteresis index $\eta$ colored by the $\mathrm{SO}_{4}^{2-} / \mathrm{NO}_{3}^{-}$mass concentration ratio, (b) wind speed (WS; unit: $\mathrm{m} \mathrm{s}{ }^{-1}$ ) colored by wind direction (WD; unit: ${ }^{\circ}$ ), and (c) ambient temperature ( $T$; unit: ${ }^{\circ} \mathrm{C}$ ) and relative humidity (RH; unit: $\left.\%\right)$. The segments of the time series with a grey background represent the processes of deliquescence. The date in this figure is in the month/day format.
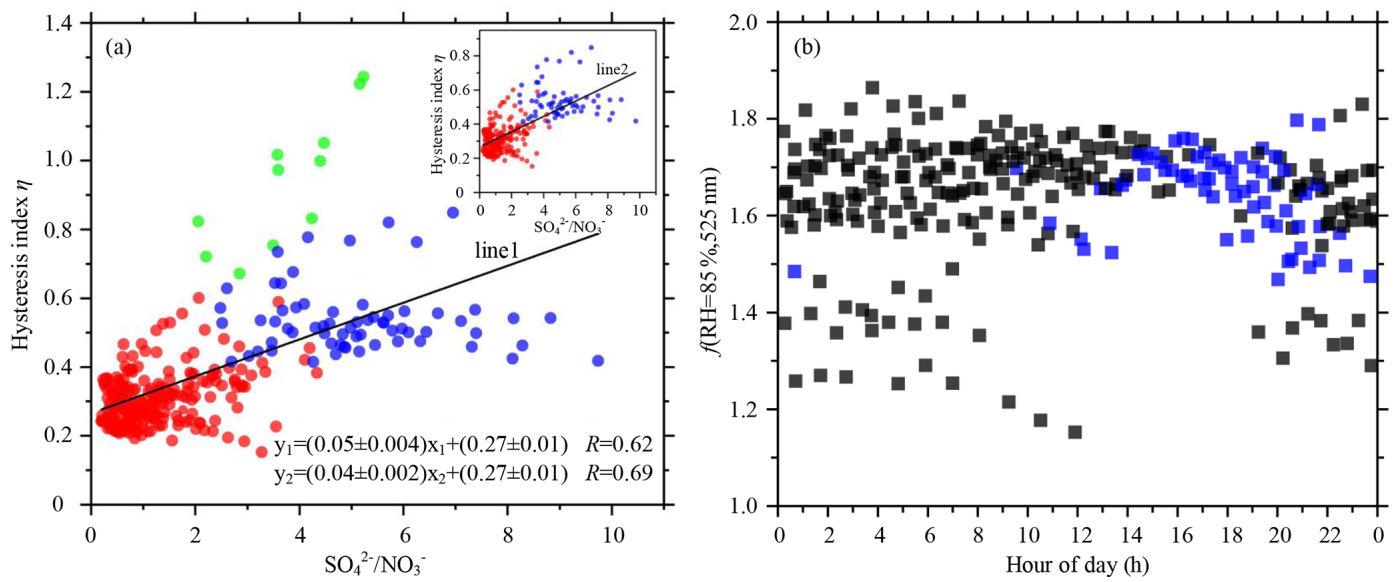

Figure 7. (a) Scatter plot of hysteresis index $\eta$ as a function of the $\mathrm{SO}_{4}^{2-} / \mathrm{NO}_{3}^{-}$mass concentration ratio. Blue dots represent deliquescence and red dots non-deliquescent processes. Green dots represent those data points with high systematic errors. The inset figure shows the scatter plot excluding the green dots. (b) Scatter plots of the observed $f(\mathrm{RH}=85 \%, 525 \mathrm{~nm})$ values for non-deliquescent (black) and deliquescent (blue) cycles. The linear regression functions and the Pearson's correlation coefficients $(R)$ are given in the bottom right corner of (a) for each fitted line. 

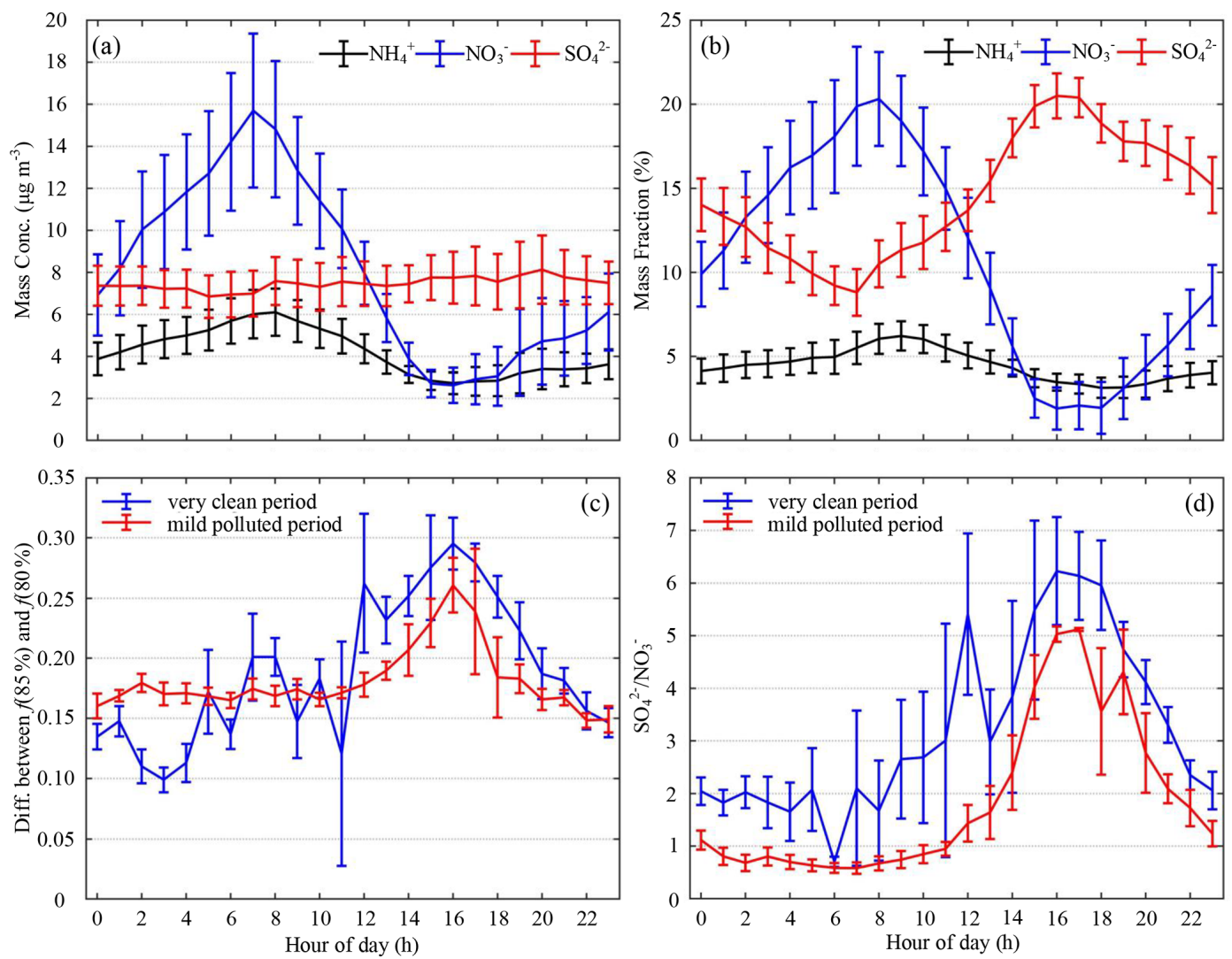

Figure 8. Average diurnal cycles of (a) mass concentration (unit: $\mu \mathrm{g} \mathrm{m}^{-3}$ ) and (b) mass fraction (unit: \%) of ammonium (black curves), nitrate (blue curves), and sulfate (red curves) measured by the ACSM. (c) The difference between $f(\mathrm{RH}=85 \%, 525 \mathrm{~nm})$ and $f(\mathrm{RH}=$ $80 \%, 525 \mathrm{~nm})$ and $(\mathbf{d})$ the mass concentration ratio of sulfate to nitrate $\left(\mathrm{SO}_{4}^{2-} / \mathrm{NO}_{3}^{-}\right)$during the clean period (blue curve) and the moderately polluted period (red curve). Vertical lines are the standard deviations.

could be generated during the day, facilitating the deliquescence of ambient aerosols.

\subsection{Parameterizations of $f(\mathrm{RH})$}

\subsubsection{Parameterization with the equation $f(\mathbf{R H})=1+m \times \mathbf{R H}^{n}$}

Many empirical expressions have been presented to parameterize $f(\mathrm{RH})$ (Kotchenruther and Hobbs, 1998; Carrico et al., 2003; Pan et al., 2009; Fierz-Schmidhauser et al., 2010a; Chen et al., 2014; Brock et al., 2016; Titos et al., 2016; Kuang et al., 2017). The following is the two-parameter scheme introduced by Kotchenruther and Hobbs (1998):

$f(\mathrm{RH})=1+m \times \mathrm{RH}^{n}$.

The parameter $m$ determines the largest value of $f(\mathrm{RH}=100 \%)$, and the parameter $n$ dominates the magnitude of the scattering enhancement, reflecting the curvature of the humidogram.

Deliquescence was frequently observed during the entire measurement campaign. In total, 294 cycles of $f(\mathrm{RH})$ were measured, and 47 cycles (16\% of all cycles) showed clear deliquescence (Fig. 9d, e). All $f(\mathrm{RH})$ curves were thus first classified into deliquescent curves and non-deliquescent curves. After averaging $\mathrm{PM}_{2.5}$ concentrations of the corresponding cycles, all non-deliquescent curves were further divided into clean $\left(\mathrm{PM}_{2.5} \leq 35 \mu \mathrm{g} \mathrm{m}^{-3}\right)$, moderately polluted $\left(35 \mu \mathrm{g} \mathrm{m}^{-3}<\mathrm{PM}_{2.5} \leq 75 \mu \mathrm{g} \mathrm{m}^{-3}\right)$, and polluted $\left(\mathrm{PM}_{2.5}>\right.$ $75 \mathrm{\mu g} \mathrm{m}^{-3}$ ) categories. The deliquescent curves were divided into clean and moderately clean categories only because deliquescence mainly occurred under good air quality conditions. For cycles without deliquescence (Fig. 9a-c), the measured values were fitted using Eq. (10). For cycles with deliquescence (Fig. 9d, e), $f(\mathrm{RH})$ increased smoothly under low RH conditions then increased sharply. Under low and high $\mathrm{RH}$ conditions, the fitted $f(\mathrm{RH})$ values were usually lower than observed values, but the slopes of the two curves were similar. However, when RH approached $\sim 80 \%$ where $f(\mathrm{RH})$ sharply increased, the fitted $f(\mathrm{RH})$ values were usually higher than observed values, with different slopes of the two curves. Therefore, segment fitting (Eq. 12) was applied in the parameterization of deliquescent $f(\mathrm{RH})$. The deliquescence observed in our study was primarily caused by $\left(\mathrm{NH}_{4}\right)_{2} \mathrm{SO}_{4}$ in ambient aerosols. The 
Table 2. Curve-fitting parameters of $f(\mathrm{RH})$ at $525 \mathrm{~nm}$ for different aerosol types using Eqs. (10) and (12).

\begin{tabular}{|c|c|c|c|c|c|c|c|}
\hline \multicolumn{3}{|c|}{ Classification } & $m$ & $n$ & $a$ & $b$ & Reference \\
\hline Non-deliquescence & $\begin{array}{l}\text { Very clean } \\
\text { Moderately polluted } \\
\text { Polluted }\end{array}$ & & $\begin{array}{l}1.32 \pm 0.07 \\
1.29 \pm 0.02 \\
1.42 \pm 0.04\end{array}$ & $\begin{array}{l}5.05 \pm 0.18 \\
3.99 \pm 0.06 \\
4.35 \pm 0.08\end{array}$ & & & \multirow[t]{3}{*}{ This study } \\
\hline \multirow[t]{2}{*}{ Deliquescence } & Very clean & $\begin{array}{l}\mathrm{RH}<78 \% \\
\mathrm{RH}>82 \% \\
78 \%<\mathrm{RH}<82 \% \\
40 \%<\mathrm{RH}<90 \%\end{array}$ & $\begin{array}{l}0.55 \pm 0.02 \\
1.63 \pm 0.10 \\
1.56 \pm 0.12\end{array}$ & $\begin{array}{l}3.51 \pm 0.09 \\
5.84 \pm 0.41 \\
5.92 \pm 0.34\end{array}$ & $0.07 \pm 0.006$ & $-4.29 \pm 0.47$ & \\
\hline & Moderately polluted & $\begin{array}{l}\mathrm{RH}<78 \% \\
\mathrm{RH}>82 \% \\
78 \%<\mathrm{RH}<82 \% \\
40 \%<\mathrm{RH}<90 \%\end{array}$ & $\begin{array}{l}0.62 \pm 0.01 \\
1.50 \pm 0.04 \\
1.26 \pm 0.11\end{array}$ & $\begin{array}{l}3.08 \pm 0.04 \\
4.88 \pm 0.19 \\
4.61 \pm 0.27\end{array}$ & $0.07 \pm 0.003$ & $-3.88 \pm 0.24$ & \\
\hline $\begin{array}{l}\text { Clean } \\
\text { Polluted } \\
\text { Dust }\end{array}$ & & & $\begin{array}{l}1.20 \pm 0.06 \\
2.30 \pm 0.03 \\
0.64 \pm 0.04\end{array}$ & $\begin{array}{r}6.70 \pm 0.27 \\
6.27 \pm 0.10 \\
5.17 \pm 0.4\end{array}$ & & & Pan et al. (2009) \\
\hline $\begin{array}{l}\text { Locally polluted } \\
\text { Northerly polluted } \\
\text { Dust-influenced }\end{array}$ & & & $\begin{array}{l}1.24 \pm 0.29 \\
1.20 \pm 0.21 \\
1.02 \pm 0.19\end{array}$ & $\begin{array}{l}5.46 \pm 1.90 \\
3.90 \pm 1.27 \\
4.51 \pm 0.80\end{array}$ & & & Zhang et al. (2015) \\
\hline
\end{tabular}
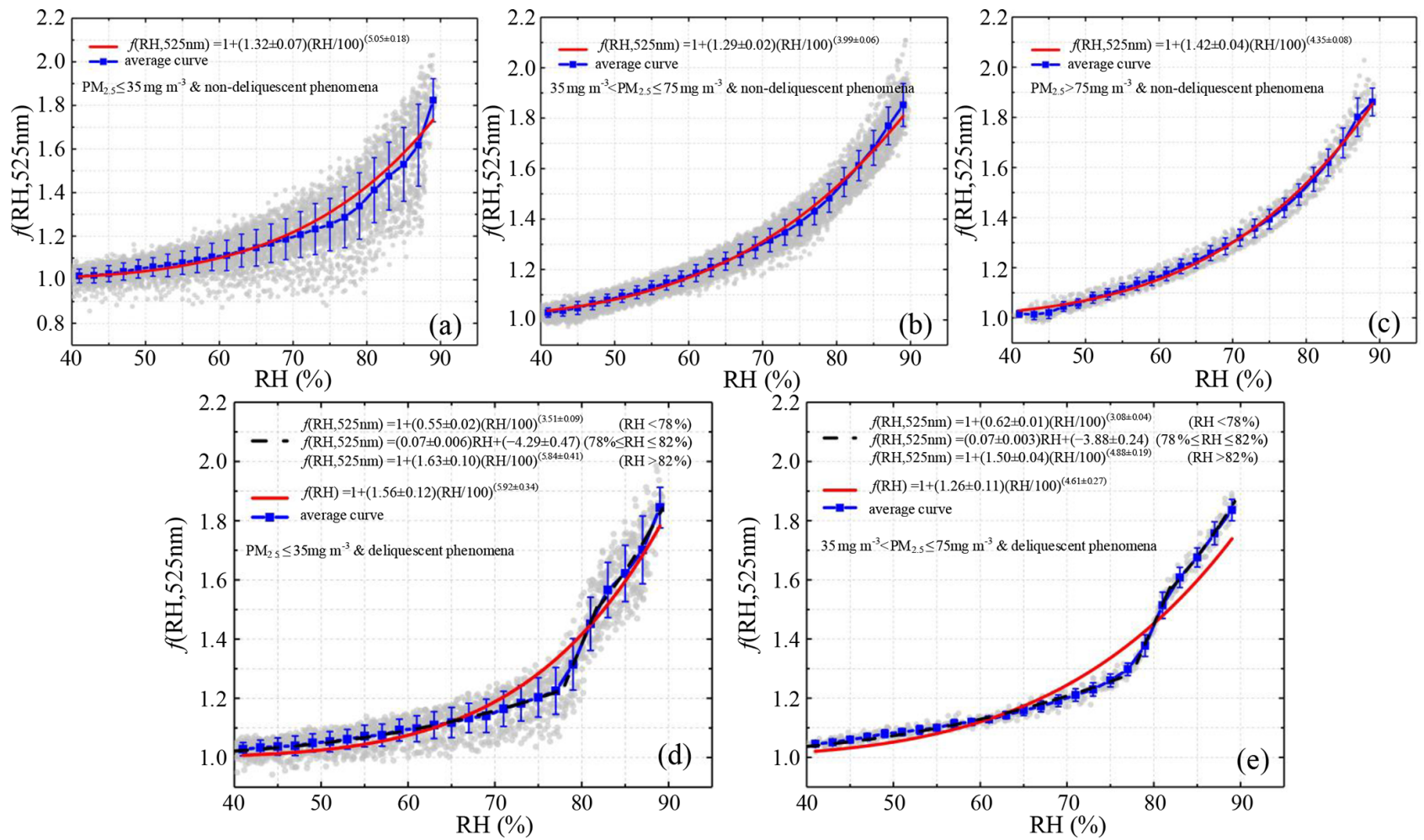

Figure 9. Fitted $f(\mathrm{RH})$ of non-deliquescent curves (a-c) and deliquescent curves (d-e) for different pollution levels. Solid red lines represent fitted curves parameterized by Eq. (10). Dotted black lines represent the curves fit by segment function Eq. (12), and the solid blue lines represent the average curves.

DRH of the pure $\left(\mathrm{NH}_{4}\right)_{2} \mathrm{SO}_{4}$ aerosols generated in the laboratory was $80.37 \%$, measured by our high-resolution humidified nephelometer system (Fig. S4). Because the DRH of all deliquescence in this study, according to statistics, was mainly distributed between $78 \%$ and $80 \%$, Eq. (10) was applied to fit $f(\mathrm{RH})$ values when $\mathrm{RH} \geq 82 \%$ or $\mathrm{RH} \leq 78 \%$.
For $78 \%<\mathrm{RH}<82 \%, f(\mathrm{RH})$ values were parameterized by Eq. (11):

$$
f(\mathrm{RH})=a \times \mathrm{RH}+b .
$$

Parameter $a$ determines the degree of $f(\mathrm{RH})$ jumps during deliquescence, i.e., the slope of the linear fitting line. Param- 
eter $b$ determines the $f(\mathrm{RH}, 525 \mathrm{~nm})$ value before deliquescence $(\mathrm{RH}=78 \%)$ and after deliquescence $(\mathrm{RH}=82 \%)$.

$\left\{\begin{array}{lrl}f(\mathrm{RH})=1+m \times \mathrm{RH}^{n} & \mathrm{RH} \leq 78 \% \\ f(\mathrm{RH})=a \times \mathrm{RH}+b & 78 \%<\mathrm{RH}<82 \% \\ f(\mathrm{RH})=1+m \times \mathrm{RH}^{n} & \mathrm{RH} \geq 82 \%\end{array}\right.$

Table 2 summarizes the parameters $m$ and $n$ used in this study and in similar studies. For the non-deliquescence case, the parameter $n$ for the clean period was the largest $(\sim 27 \%$ larger than that for the moderately polluted period and $\sim 16 \%$ larger than that for the polluted period). The difference between the clean and moderately polluted parameter $m$ was small, while the parameter $m$ in the polluted period was about 0.1 larger than that in the other two periods. As a result, $f(\mathrm{RH}=85 \%, 525 \mathrm{~nm})$ was the largest in the polluted period and the smallest in the clean period. For the deliquescence case, the fitted parameters $m$ and $n$ for the whole RH range $(40 \%<\mathrm{RH}<90 \%)$ were much larger than the $m$ and $n$ for $\mathrm{RH}<78 \%$. If Eq. (10) was used to parameterize the whole RH range of the deliquescence curves instead of segment fitting, bigger differences between the parameterized fitting results and measured values would occur. This would cause greater uncertainties in the model simulation of aerosol hygroscopicity. Also, there was no significant difference between parameter $a$ under clean $(a=0.07 \pm 0.006)$ and moderately polluted ( $a=0.07 \pm 0.003$ ) conditions, indicating that the trend and amplitude of the jump growth for aerosol deliquescence are consistent under these two environmental conditions. However, the absolute value of parameter $b$ under clean conditions $(b=-4.29 \pm 0.47)$ was higher than that under moderately polluted conditions $(b=-3.88 \pm 0.24)$, indicating that the DRH for clean periods was slightly higher than that for moderately polluted periods.

\subsubsection{Steepness of humidograms}

The steepness index proposed by Zhang et al. (2015), $\tau$, is defined as

$\tau=\frac{f^{\prime}(80 \%)}{f^{\prime}(60 \%)}-1=\left(\frac{4}{3}\right)^{n-1}-1$

to quantitatively describe the change in the curvature of the humidogram curves; $f^{\prime}(80 \%)$ and $f^{\prime}(60 \%)$ are the derivatives of the fitted curve of $f(\mathrm{RH})$ given in Eq. (10) at the two different $\mathrm{RH}$ values.

A low $\tau$ means that the curvature of the humidogram is small, and a high $\tau$ means that the slopes of the curve from low to high RH sharply change. Figure S11 shows the scatter plot of $\tau$ as a function of the nitrate mass fraction, colored by the sulfate mass fraction. In the $0 \%-15 \%$ nitrate mass fraction range, $\tau$ decreased sharply as the nitrate mass fraction increased, demonstrating that the curvature of the humidogram became smaller. For nitrate mass fractions larger than $15 \%, \tau$ stabilized to a constant value of $\sim 1.6$, and the curvature of the humidogram was much smaller.

\section{Conclusions}

Direct measurements of aerosol hygroscopicity, as expressed by $f(\mathrm{RH}, \lambda)$, were carried out at a site in the southern urban edge of Beijing, aimed at investigating the effect of aerosol water uptake on particle light-scattering properties. The mass concentrations of aerosol chemical components were measured simultaneously by the ACSM and AE-33. Also measured were other aerosol parameters, such as the light absorption coefficient and the mass concentration of $\mathrm{PM}_{2.5}$. In total, 294 cycles of $f(\mathrm{RH})$ were measured, and 47 cycles (16\% of all cycles) showed clear deliquescence.

The proportion of components making up the chemical composition of aerosols is key to influencing $f(\mathrm{RH})$. In general, $f(\mathrm{RH})$ had a strong positive correlation with the proportion of inorganic matter and a negative correlation with the proportion of organic matter and eBC. High values of $f(\mathrm{RH})$ usually occurred for aged aerosols whose mass fraction of organic matter was small. Low values of $f(\mathrm{RH}=85 \%, 525 \mathrm{~nm})$ often occurred for primary aerosols with more organic matter. Furthermore, when the mass fraction of inorganic matter was smaller than $40 \%$, the positive correlation between $f(\mathrm{RH}=85 \%, 525 \mathrm{~nm})$ and inorganic matter was much stronger. A similar phenomenon was also found for the negative correlation between organic matter and $f(\mathrm{RH}=85 \%, 525 \mathrm{~nm})$. The compensating effect between the size and chemical composition of aerosol may be one of the main reasons for this phenomenon. High mass concentrations of ambient aerosols and insufficient water vapor in the sample flow may be the other two reasons. Nitrate also played a more significant role in affecting aerosol hygroscopic growth than sulfate in Beijing.

Favorable meteorological conditions for aerosol deliquescence were high ambient temperature and low $\mathrm{RH}$, as well as relatively good air quality and strong solar illumination. High temperatures and low RH levels were not conducive to the formation of nitrate, while good air quality and light conditions were conducive to photochemical reactions so that more secondary sulfates could be generated. Only when the ratio of the sulfate mass fraction to the nitrate mass fraction was greater than $\sim 4$ did the deliquescence phenomenon of ambient aerosols easily occur.

All humidograms were first classified as either deliquescent or non-deliquescent. The two kinds of humidograms were further classified according to the mass concentration of $\mathrm{PM}_{2.5}$. The two-parameter scheme, $f(\mathrm{RH})=1+m \times \mathrm{RH}^{n}$, introduced by Kotchenruther and Hobbs (1998), was applied to fit the non-deliquescent $f(\mathrm{RH})$. The deliquescent $f(\mathrm{RH})$ was parameterized by segment functions (Eq. 12). For the deliquescence case, the fitted parameters $m$ and $n$ for the whole $\mathrm{RH}$ range $(40 \%<\mathrm{RH}<90 \%)$ were much larger than the parameters for $\mathrm{RH}<78 \%$. This demonstrates that large errors would be incurred if only Eq. (10) was used to parameterize the whole $\mathrm{RH}$ range of deliquescence curves. The piecewise parameterization scheme (Eq. 12) is a better fit 
for humidograms representing deliquescence to reduce uncertainties in the model simulation of aerosol hygroscopicity. The curvature of the $f(\mathrm{RH})$ humidogram, described by the steepness index, decreased sharply as the nitrate mass fraction increased within the range of $0 \%-15 \%$. When the nitrate mass fraction was larger than $15 \%$, the steepness index remained constant $(\sim 1.6)$.

Data availability. The data used in this paper can be downloaded online (https://doi.org/10.11922/sciencedb.00785, last access: 6 May 2021, Ren, 2021).

Supplement. The supplement related to this article is available online at: https://doi.org/10.5194/acp-21-9977-2021-supplement.

Author contributions. ZL and PY designed the field experiment. ZL, PY, and RR determined the main goal of this study. RR processed the measurement data and prepared this paper with contributions from all co-authors. PY, HW, and YW provided technical guidance for instrumentation. MC copy-edited the article. WW, XJ, $\mathrm{YL}$, and DZ participated in the implementation of this experiment.

Competing interests. The authors declare that they have no conflict of interest.

Financial support. This work was funded by the National Key R\&D Program of the Ministry of Science and Technology, China (grant no. 2017YFC1501702), National Natural Science Foundation of China (NSFC) research projects (grant nos. 42030606 and 42005067), and the Guangdong Basic and Applied Basic Research Fund Committee (grant no. 2020B1515130003).

Review statement. This paper was edited by Paul Zieger and reviewed by two anonymous referees.

\section{References}

Anderson, T. L. and Ogren, J. A.: Determining aerosol radiative properties using the TSI 3563 integrating nephelometer, Aerosol Sci. Tech., 29, 57-69, https://doi.org/10.1080/02786829808965551, 1998.

Bond, T. C. and Bergstrom, R. W.: Light absorption by carbonaceous particles: an investigative review, Aerosol Sci. Tech., 40, 27-67, https://doi.org/10.1080/02786820500421521, 2006.

Brock, C. A., Wagner, N. L., Anderson, B. E., Attwood, A. R., Beyersdorf, A., Campuzano-Jost, P., Carlton, A. G., Day, D. A., Diskin, G. S., Gordon, T. D., Jimenez, J. L., Lack, D. A., Liao, J., Markovic, M. Z., Middlebrook, A. M., Ng, N. L., Perring, A. E., Richardson, M. S., Schwarz, J. P., Washenfelder, R. A., Welti, A., Xu, L., Ziemba, L. D., and Murphy, D. M.: Aerosol optical properties in the southeastern United States in summer - Part 1: Hygroscopic growth, Atmos. Chem. Phys., 16, 49875007, https://doi.org/10.5194/acp-16-4987-2016, 2016.

Carrico, C. M., Rood, M. J., and Ogren, J. A.: Aerosol light scattering properties at Cape Grim, Tasmania, during the First Aerosol Characterization Experiment (ACE 1), J. Geophys. Res.-Atmos., 103, 16565-16574, https://doi.org/10.1029/98JD00685, 1998.

Carrico, C. M., Kus, P., Rood, M. J., Quinn, P. K., and Bates, T. S.: Mixtures of pollution, dust, sea salt, and volcanic aerosol during ACE: radiative properties as a function of relative humidity, J. Geophys. Res.-Atmos., 108, 8650, https://doi.org/10.1029/2003JD003405, 2003.

Chen, J., Zhao, C. S., Ma, N., and Yan, P.: Aerosol hygroscopicity parameter derived from the light scattering enhancement factor measurements in the North China Plain, Atmos. Chem. Phys., 14, 8105-8118, https://doi.org/10.5194/acp-14-8105-2014, 2014.

Cheung, H. H. Y., Yeung, M. C., Li, Y. J., Lee, B. P., and Chan, C. K.: Relative humidity-dependent TDMA measurements of ambient aerosols at the HKUST supersite in Hong Kong, China, Aerosol Sci. Tech., 49, 643-654, https://doi.org/10.1080/02786826.2015.1058482, 2015.

Doherty, S. J., Quinn, P. K., Jefferson, A., Carrico, C. M., Anderson, T. L., and Hegg, D.: A comparison and summary of aerosol optical properties as observed in situ from aircraft, ship, and land during ACE-Asia, J. Geophys. Res. Atmos., 110, D04201, https://doi.org/10.1029/2004jd004964, 2005.

Fierz-Schmidhauser, R., Zieger, P., Gysel, M., Kammermann, L., DeCarlo, P. F., Baltensperger, U., and Weingartner, E.: Measured and predicted aerosol light scattering enhancement factors at the high alpine site Jungfraujoch, Atmos. Chem. Phys., 10, 23192333, https://doi.org/10.5194/acp-10-2319-2010, 2010a.

Fierz-Schmidhauser, R., Zieger, P., Wehrle, G., Jefferson, A., Ogren, J. A., Baltensperger, U., and Weingartner, E.: Measurement of relative humidity dependent light scattering of aerosols, Atmos. Meas. Tech., 3, 39-50, https://doi.org/10.5194/amt-3-392010, 2010b.

Gysel, M., Crosier, J., Topping, D. O., Whitehead, J. D., Bower, K. N., Cubison, M. J., Williams, P. I., Flynn, M. J., McFiggans, G. B., and Coe, H.: Closure study between chemical composition and hygroscopic growth of aerosol particles during TORCH2, Atmos. Chem. Phys., 7, 6131-6144, https://doi.org/10.5194/acp7-6131-2007, 2007.

Han, T., Xu, W., Chen, C., Liu, X., Wang, Q., Li, J., Zhao, X., Du, W., Wang, Z., and Sun, Y.: Chemical apportionment of aerosol optical properties during the Asia Economic Cooperation summit in Beijing, China, J. Geophys. Res. Atmos., 120, 12281-12295, https://doi.org/10.1002/2015JD023918, 2015.

Huang, X.-F., He, L.-Y., Hu, M., Canagaratna, M. R., Sun, Y., Zhang, Q., Zhu, T., Xue, L., Zeng, L.-W., Liu, X.-G., Zhang, Y.-H., Jayne, J. T., Ng, N. L., and Worsnop, D. R.: Highly time-resolved chemical characterization of atmospheric submicron particles during 2008 Beijing Olympic Games using an Aerodyne High-Resolution Aerosol Mass Spectrometer, Atmos. Chem. Phys., 10, 8933-8945, https://doi.org/10.5194/acp-108933-2010, 2010.

IPCC: Climate Change 2013: The Physical Science Basis, Cambridge University Press, Cambridge, United Kingdom and New York, NY, USA, 1535 pp., 2013. 
James, D. J., Brianna, M. M., Dennis, E., Scott, C. C., and Scott, A. B.: Comparison of Single-Point and Continuous Sampling Methods for Estimating Residential Indoor Temperature and Humidity, J. Occup. Environ. Hyg., 12, 785-794, https://doi.org/10.1080/15459624.2015.1047024, 2015.

Jin, X., Wang, Y., Li, Z., Zhang, F., Xu, W., Sun, Y., Fan, X., Chen, G., Wu, H., Ren, J., Wang, Q., and Cribb, M.: Significant contribution of organics to aerosol liquid water content in winter in Beijing, China, Atmos. Chem. Phys., 20, 901-914, https://doi.org/10.5194/acp-20-901-2020, 2020.

Kotchenruther, R. A. and Hobbs, P. V.: Humidification factors of aerosols from biomass burning in Brazil, J. Geophys. Res.Atmos., 103, 32081-32089, https://doi.org/10.1029/98JD00340, 1998.

Kuang, Y., Zhao, C. S., Ma, N., Liu, H. J., Bian, Y. X., Tao, J. C., and $\mathrm{Hu}, \mathrm{M}$.: Deliquescent phenomena of ambient aerosols on the North China Plain, Geophys. Res. Lett., 43, 8744-8750, https://doi.org/10.1002/2016gl070273, 2016.

Kuang, Y., Zhao, C., Tao, J., Bian, Y., Ma, N., and Zhao, G.: A novel method for deriving the aerosol hygroscopicity parameter based only on measurements from a humidified nephelometer system, Atmos. Chem. Phys., 17, 6651-6662, https://doi.org/10.5194/acp-17-6651-2017, 2017.

Li, H., Cheng, J., Zhang, Q., Zheng, B., Zhang, Y., Zheng, G., and He, K.: Rapid transition in winter aerosol composition in Beijing from 2014 to 2017: response to clean air actions, Atmos. Chem. Phys., 19, 11485-11499, https://doi.org/10.5194/acp-19-114852019, 2019.

Li, Z., Wang, Y., Guo, J., Zhao, C., Cribb, M. C., Dong, X., Fan, J., Gong, D., Huang, J., Jiang, M., Jiang, Y., Lee, S.-S., Li, H., Li, J., Liu, J., Qian, Y., Rosenfeld, D., Shan, S., Sun, Y., Wang, H., Xin, J., Yan, X., Yang, X., Yang, X.-Q., Zhang, F., and Zheng, Y.: East Asian Study of Tropospheric Aerosols and their Impact on Regional Clouds, Precipitation, and Climate (EAST-AIRCPC), J. Geophys. Res.-Atmos., 124, 13026-13054, https://doi.org/10.1029/2019jd030758, 2019.

Liu, H. and Zhao, C.: Design of a humidified nephelometer system with high time resolution, Acta Scientiarum Naturalium Universitatis Pekinensis, 52, 999-1004, https://doi.org/10.13209/j.0479-8023.2016.053, 2016.

Liu, C., Chung, C. E., Yin, Y., and Schnaiter, M.: The absorption Ångström exponent of black carbon: from numerical aspects, Atmos. Chem. Phys., 18, 6259-6273, https://doi.org/10.5194/acp18-6259-2018, 2018.

Liu, L., Tan, H., Fan, S., Cai, M., Xu, H., Li, F., and Chan, P.: Influence of aerosol hygroscopicity and mixing state on aerosol optical properties in the Pearl River Delta region, China, Sci. Total Environ., 627, 1560-1571, https://doi.org/10.1016/j.scitotenv.2018.01.199, 2018.

Liu, X. G., Li, J., Qu, Y., Han, T., Hou, L., Gu, J., Chen, C., Yang, Y., Liu, X., Yang, T., Zhang, Y., Tian, H., and Hu, M.: Formation and evolution mechanism of regional haze: a case study in the megacity Beijing, China, Atmos. Chem. Phys., 13, 4501-4514, https://doi.org/10.5194/acp-13-4501-2013, 2013.

Müller, T., Laborde, M., Kassell, G., and Wiedensohler, A.: Design and performance of a three-wavelength LED-based total scatter and backscatter integrating nephelometer, Atmos. Meas. Tech., 4, 1291-1303, https://doi.org/10.5194/amt-4-1291-2011, 2011.
Monks, P. S., Granier, C., Fuzzi, S., Stohl, A., Williams, M. L., Akimoto, H., Amann, M., Baklanov, A., Baltensperger, U., Bey, I., Blake, N., Blake, R. S., Carslaw, K. S., Cooper, O. R., Dentener, F. J., Fowler, D., Fragkou, E., Frost, G. J., Generoso, S., Ginoux, P., Grewe, V., Guenther, A., Hansson, H. C., Henne, S., Hjorth, J., Hofzumahaus, A., Huntrieser, H., Isaksen, I. S. A., Jenkin, M. E., Kaiser, J., Kanakidou, M., Klimont, Z., Kulmala, M., Laj, P., Lawrence, M. G., Lee, J. D., Liousse, C., Maione, M., McFiggans, G. B., Metzger, A., Mieville, A., Moussiopoulos, N., Orlando, J. J., O'Dowd, C. D., Palmer, P. I., Parrish, D. D., Petzold, A., Platt, U., Poschl, U., A.S.H. Prévôt, A. S. H., Reeves, C. E., Reimann, S., Rudich, Y., Sellegri, K., Steinbrecher, R., Simpson, D., ten Brink, H., Theloke, J., van Der Werf, G. R., Vautard, R., Vestreng, V., Vlachokostas, C., and von Glasow, R.: Atmospheric composition change global and regional air quality, Atmos. Environ., 43, 5268-5350, https://doi.org/10.1016/j.atmosenv.2009.08.021, 2009.

Morgan, W. T., Allan, J. D., Bower, K. N., Esselborn, M., Harris, B., Henzing, J. S., Highwood, E. J., Kiendler-Scharr, A., McMeeking, G. R., Mensah, A. A., Northway, M. J., Osborne, S., Williams, P. I., Krejci, R., and Coe, H.: Enhancement of the aerosol direct radiative effect by semi-volatile aerosol components: airborne measurements in North-Western Europe, Atmos. Chem. Phys., 10, 8151-8171, https://doi.org/10.5194/acp10-8151-2010, 2010.

Morino, Y., Kondo, Y., Takegawa, N., Miyazaki, Y., Kita, K., Komazaki, Y., Fukuda, M., Miyakawa, T., Moteki, N., and Worsnop, D. R.: Partitioning of $\mathrm{HNO}_{3}$ and particulate nitrate over Tokyo: effect of vertical mixing, J. Geophys. Res. Atmos., 111, D15215, https://doi.org/10.1029/2005jd006887, 2006.

Pan, X. L., Yan, P., Tang, J., Ma, J. Z., Wang, Z. F., Gbaguidi, A., and Sun, Y. L.: Observational study of influence of aerosol hygroscopic growth on scattering coefficient over rural area near Beijing mega-city, Atmos. Chem. Phys., 9, 7519-7530, https://doi.org/10.5194/acp-9-7519-2009, 2009.

Quinn, P. K., Bates, T. S., Baynard, T., Clarke, A. D., Onasch, T. B., Wang, W., Rood, M. J., Andrews, E., Allan, J., Carrico, C. M., Coffman, D., and Worsnop, D.: Impact of particulate organic matter on the relative humidity dependence of light scattering: a simplified parameterization, Geophys. Res. Lett., 32, L22809, https://doi.org/10.1029/2005g1024322, 2005.

Ren, R.: A dataset of the comprehensive field experiment for BNU, Beijing, China, V1 [data set], available at: http://www.doi.org/ 10.11922/sciencedb.00785, last access: 6 May 2021.

Shi, Y., Chen, J., Hu, D., Wang, L., Yang, X., and Wang, X.: Airborne submicron particulate $\left(\mathrm{PM}_{1}\right)$ pollution in Shanghai, China: chemical variability, formation/dissociation of associated semi-volatile components and the impacts on visibility, Sci. Total Environ., 473, 199-206, https://doi.org/10.1016/j.scitotenv.2013.12.024, 2014.

Sun, Y., Wang, Z., Dong, H., Yang, T., Li, J., Pan, X., Chen, P., and Jayne, J. T.: Characterization of summer organic and inorganic aerosols in Beijing, China with an aerosol chemical speciation monitor, Atmos. Environ., 51, 250-259, https://doi.org/10.1016/j.atmosenv.2012.01.013, 2012.

Titos, G., Cazorla, A., Zieger, P., Andrews, E., Lyamani, H., Granadosmunoz, M. J., Olmo, F. J., and Aladosarboledas, L.: Effect of hygroscopic growth on the aerosol light-scattering coefficient: a review of measurements, tech- 
niques and error sources, Atmos. Environ., 141, 494-507, https://doi.org/10.1016/j.atmosenv.2016.07.021, 2016.

Wang, X., Zhang, Y., Chen, H., Yang, X., Chen, J., and Geng, F.: Particulate nitrate formation in a highly polluted urban area: a case study by single-particle mass spectrometry in Shanghai, Environ. Sci. Technol., 43, 3061-3066, https://doi.org/10.1021/es8020155, 2009.

Wang, Y., Zhang, F., Li, Z., Tan, H., Xu, H., Ren, J., Zhao, J., Du, W., and Sun, Y.: Enhanced hydrophobicity and volatility of submicron aerosols under severe emission control conditions in Beijing, Atmos. Chem. Phys., 17, 5239-5251, https://doi.org/10.5194/acp-17-5239-2017, 2017.

Wang, Y., Li, Z., Zhang, Y., Du, W., Zhang, F., Tan, H., Xu, H., Fan, T., Jin, X., Fan, X., Dong, Z., Wang, Q., and Sun, Y.: Characterization of aerosol hygroscopicity, mixing state, and $\mathrm{CCN}$ activity at a suburban site in the central North China Plain, Atmos. Chem. Phys., 18, 11739-11752, https://doi.org/10.5194/acp-18-117392018, 2018.

Wang, Y., Li, Z., Zhang, R., Jin, X., Xu, W., Fan, X., Wu, H., Zhang, F., Sun, Y., Wang, Q., Cribb, M., and Hu, D.: Distinct ultrafine-and accumulation-mode particle properties in clean and polluted urban environments, Geophys. Res. Lett., 46, 10918 10925, https://doi.org/10.1029/2019GL084047, 2019.

Wanielista, M., Kersten, R., and Eaglin, R.: Hydrology: Water Quantity and Quality Control, 2nd edition, John Wiley \& Sons, New York, the United States, 567 pp., 1997.

Wu, T., Li, Z., Chen, J., Wang, Y., Wu, H., Jin, X., Liang, C., Li, S., Wang, W., and Cribb, M.: Hygroscopicity of different types of aerosol particles: case studies using multiinstrument data in megacity Beijing, China, Remote Sens., 12, 785, https://doi.org/10.3390/rs12050785, 2020.

Wu, Y., Wang, X., Yan, P., Zhang, L., Tao, J., Liu, X., Tian, P., Han, Z., and Zhang, R.: Investigation of hygroscopic growth effect on aerosol scattering coefficient at a rural site in the southern North China Plain, Sci. Total Environ., 599, 76-84, https://doi.org/10.1016/j.scitotenv.2017.04.194, 2017.

Xu, W., Sun, Y., Wang, Q., Zhao, J., Wang, J., Ge, X., Xie, C., Zhou, W., Du, W., Li, J., Fu, P., Wang, Z., Worsnop, D. R., and Coe, H.: Changes in aerosol chemistry from 2014 to 2016 in winter in Beijing: insights from high-resolution aerosol mass spectrometry, J. Geophys. Res.-Atmos., 124, 1132-1147, https://doi.org/10.1029/2018JD029245, 2019.

Yan, P., Pan, X., Tang, J., Zhou, X., Zhang, R., and Zeng, L.: Hygroscopic growth of aerosol scattering coefficient: a comparative analysis between urban and suburban sites at winter in Beijing, Particuology, 7, 52-60, https://doi.org/10.1016/j.partic.2008.11.009, 2009.

Yang, Y. R., Liu, X. G., Qu, Y., An, J. L., Jiang, R., Zhang, Y. H., Sun, Y. L., Wu, Z. J., Zhang, F., Xu, W. Q., and Ma, Q. X.: Characteristics and formation mechanism of continuous hazes in China: a case study during the autumn of 2014 in the North China Plain, Atmos. Chem. Phys., 15, 8165-8178, https://doi.org/10.5194/acp-15-8165-2015, 2015.

Yu, Y., Zhao, C., Kuang, Y., Tao, J., Zhao, G., Shen, C., and Xu, W.: A parameterization for the light scattering enhancement factor with aerosol chemical compositions, Atmos. Environ., 191, 370377, https://doi.org/10.1016/j.atmosenv.2018.08.016, 2018.

Zhang, L., Sun, J. Y., Shen, X. J., Zhang, Y. M., Che, H., Ma, Q. L., Zhang, Y. W., Zhang, X. Y., and Ogren, J. A.: Observa- tions of relative humidity effects on aerosol light scattering in the Yangtze River Delta of China, Atmos. Chem. Phys., 15, 84398454, https://doi.org/10.5194/acp-15-8439-2015, 2015.

Zhang, Q., Zheng, Y., Tong, D., Shao, M., Wang, S., Zhang, Y., Xu, X., Wang, J., He, H., Liu, W., Ding, Y., Lei, Y., Li, J., Wang, Z., Zhang, X., Wang, Y., Cheng, J., Liu, Y., Shi, Q., Yan, L., Geng, G., Hong, C., Li, M., Liu, F., Zheng, B., Cao, J., Ding, A., Gao, J., Fu, Q., Huo, J., Liu, B., Liu, Z., Yang, F., He, K., and Hao, J.: Drivers of improved $\mathrm{PM}_{2.5}$ air quality in China from 2013 to 2017, P. Natl. Acad. Sci. USA, 116, 24463-24469, https://doi.org/10.1073/pnas.1907956116, 2019.

Zhao, C., Yu, Y., Kuang, Y., Tao, J., and Zhao, G.: Recent progress of aerosol light-scattering enhancement factor studies in China, Adv. Atmos. Sci., 36, 1015-1026, https://doi.org/10.1007/s00376-019-8248-1, 2019.

Zhao, G., Zhao, C., Kuang, Y., Bian, Y., Tao, J., Shen, C., and Yu, Y.: Calculating the aerosol asymmetry factor based on measurements from the humidified nephelometer system, Atmos. Chem. Phys., 18, 9049-9060, https://doi.org/10.5194/acp-189049-2018, 2018.

Zhao, P., Ding, J., Du, X., and Su, J.: High time-resolution measurement of light scattering hygroscopic growth factor in Beijing: a novel method for high relative humidity conditions, Atmos. Environ., 215, 116912, https://doi.org/10.1016/j.atmosenv.2019.116912, 2019.

Zieger, P., Fierz-Schmidhauser, R., Gysel, M., Ström, J., Henne, S., Yttri, K. E., Baltensperger, U., and Weingartner, E.: Effects of relative humidity on aerosol light scattering in the Arctic, Atmos. Chem. Phys., 10, 3875-3890, https://doi.org/10.5194/acp10-3875-2010, 2010.

Zieger, P., Fierz-Schmidhauser, R., Weingartner, E., and Baltensperger, U.: Effects of relative humidity on aerosol light scattering: results from different European sites, Atmos. Chem. Phys., 13, 10609-10631, https://doi.org/10.5194/acp-13-106092013, 2013.

Zieger, P., Fierz-Schmidhauser, R., Poulain, L., Müller, T. J., Birmili, W., Spindler, G., Wiedensohler, A., Baltensperger, U., and Weingartner, E.: Influence of water uptake on the aerosol particle light-scattering coefficients of the Central European aerosol, Tellus B, 66, 22716, https://doi.org/10.3402/tellusb.v66.22716, 2014.

Zieger, P., Aalto, P. P., Aaltonen, V., Äijälä, M., Backman, J., Hong, J., Komppula, M., Krejci, R., Laborde, M., Lampilahti, J., de Leeuw, G., Pfüller, A., Rosati, B., Tesche, M., Tunved, P., Väänänen, R., and Petäjä, T.: Low hygroscopic scattering enhancement of boreal aerosol and the implications for a columnar optical closure study, Atmos. Chem. Phys., 15, 7247-7267, https://doi.org/10.5194/acp-15-7247-2015, 2015.

Zou, J., Yang, S., Hu, B., Liu, Z., Gao, W., Xu, H., Du, C., Wei, J., Ma, Y., Ji, D., and Wang, Y.: A closure study of aerosol optical properties as a function of RH using a $\kappa$-AMSBC-Mie model in Beijing, China, Atmos. Environ., 197, 1-13, https://doi.org/10.1016/j.atmosenv.2018.10.015, 2019. 